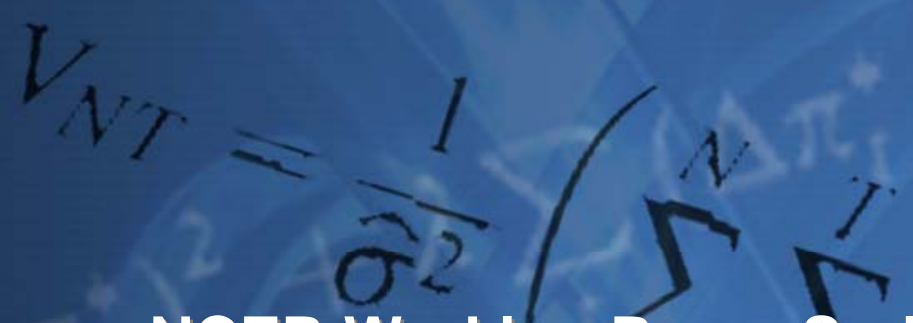

NCER Working Paper Seriés

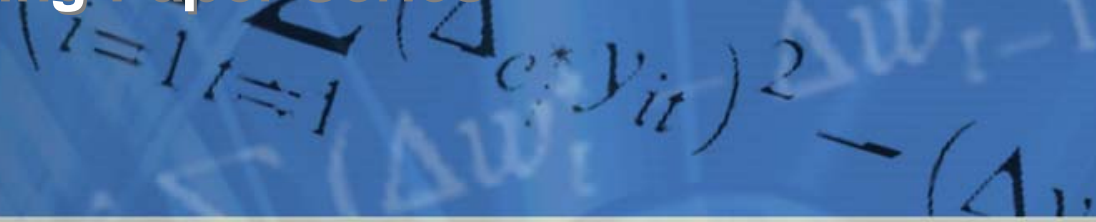

\title{
Comparing Different Explanations of the Volatility Trend
}

Amir Rubin

Daniel Smith

Working Paper \#68

November 2010

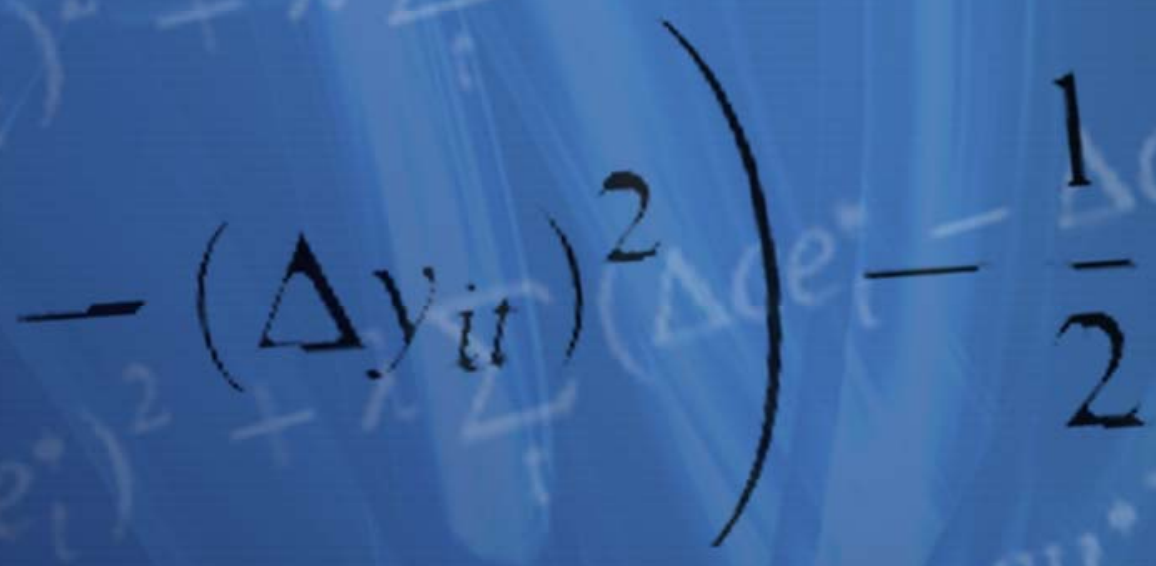




\title{
Comparing different explanations of the volatility trend ${ }^{\mathbf{1}}$
}

\author{
Amir Rubin ${ }^{\mathrm{a}, *}$, Daniel R. Smith ${ }^{\mathrm{b}}$ \\ a Simon Fraser University and Interdisciplinary Center (IDC), Herzliya \\ b Simon Fraser University and Queensland University of Technology
}

This version: October 30, 2010

\begin{abstract}
:
We analyze the puzzling behavior of the volatility of individual stock returns over the past few decades. The literature has provided many different explanations to the trend in volatility and this paper tests the viability of the different explanations. Virtually all current theoretical arguments that are provided for the trend in the average level of volatility over time lend themselves to explanations about the difference in volatility levels between firms in the cross-section. We therefore focus separately on the crosssectional and time-series explanatory power of the different proxies. We fail to find a proxy that is able to explain both dimensions well. In particular, we find that Cao et al. (2008) market-to-book ratio tracks average volatility levels well, but has no crosssectional explanatory power. On the other hand, the low-price proxy suggested by Brandt et al. (2010) has much cross-sectional explanatory power, but has virtually no time-series explanatory power. We also find that the different proxies do not explain the trend in volatility in the period prior to 1995 (R-squared of virtually zero), but explain rather well the trend in volatility at the turn of the Millennium (1995-2005).
\end{abstract}

JEL classification: G32; G35

Keywords: Volatility; Trend; Turnover.

\footnotetext{
${ }^{1}$ Earlier drafts of this paper appeared with the title: Alternative Explanations of the Volatility Trend: Are They Really That Different?

*Corresponding author. Tel.: +1 778782 5834; fax: +1 7787824920.

E-mail addresses: arubin@sfu.ca (Amir Rubin),drsmith@sfu.ca (Daniel Smith).

We thank the editor (Ike Mathur), an anonymous referee, Mark Kamstra, Richard Rouback, Avi Wohl, and seminar participants at the 2008 Northern Finance Association Meetings and 2009 Eastern Finance Association meeting for their comments on earlier drafts of the paper. The authors gratefully acknowledge the research support of the Social Sciences and Humanities Research Council of Canada.
} 


\section{Introduction}

Campbell, Lettau, Malkiel, and $\mathrm{Xu}$ (2001) and $\mathrm{Xu}$ and Malkiel (2003) demonstrated that firm-level volatility exhibited an upward trend between the early 1960s and the late 1990s. This observation led to a flurry of corporate finance research that has attempted to rationalize this trend. The overall conclusion from this subsequent research is that the change in volatility is explained by the increased importance of Nasdaq firms and risky industries (Schwert, 2002; Bennett and Sias, 2006); the increased ownership of institutions (Xu and Malkiel, 2003); the younger listing age of a firm (Fink et al., 2006); the increased cash flow risk of newly listed firms (Brown and Kapadia, 2006); the increased uncertainty in profitability (Wei and Zhang, 2006; Pastor and Veronesi, 2006); the increased product market competition (Irvine and Pontiff, 2009); the increased level and variance of firm growth options (Hollifield, 2002, Cao et al., 2008); and the low stock price of many firms during speculative market episodes such as the one witnessed in the late 1990s (Brandt et al., 2010).

To understand the scope of the previous literature we list the variables used in these studies in Table 1. Despite there being many competing explanations proposed in the literature there has been little systematic effort to reconcile the various explanations. Noting that these various explanations are related (e.g., younger firms tend to trade on Nasdaq, have high growth options, have lower prices, do not pay dividends, and have high volatility in cash flows) and given that most of these explanations seem to relate to structural changes in the financial markets in the 90's (with the emergence and growth of the technology sector), it seems natural to ask two questions: How "different" the different competing explanations actually are, and do these explanations track the trend in 
volatility prior to the structural change in the mid 90's.

In this paper we analyze the viability of the different explanations proposed in the literature for the time-trend in average volatility level. We adopt an expansive analysis focusing on many variables using both time-series and cross-sectional analysis. We find that many of the variables considered work well in one context but fail dismally in the other. We also find that the relationship between volatility and the different proxies exhibits a structural break around 1995. Since variables are able to explain the behavior of volatility during some sub-periods but not others we clearly do not have a robust theoretical picture of what drives volatility.

In Figure 1 we plot the market value-weighted averages of quarterly volatility, quarterly excess industry volatility, and quarterly sum of squared errors from a daily return regression estimation that includes the three-factor Fama and French (1993) model including the Carhart (1997) momentum factor (hence, four-factor model). The calculation is based on daily returns in the same way that was done by Campbell et al. (2001) for the first two measures, and based on quarterly regressions of daily returns residuals for the four-factor model. As shown in the Figure 1, the trend in total volatility, the trend in idiosyncratic volatility based on the Campbell et al. (2001) decomposition, and the trend in idiosyncratic volatility based on the four-factor model, are virtually the same. We show that past studies could have easily done their analyses on total volatility, and the much attention given in past studies to different types of volatility decomposition is redundant. ${ }^{2}$ Also apparent from the figure is that the trend Campbell et al. (2001)

\footnotetext{
${ }^{2}$ Note from Table 1 that different studies measure idiosyncratic risk differently. We find that the differences between different volatility variables are unimportant both for time-series and cross-sectional analyses. Arguably, it is somewhat misleading to refer to these studies as studies of idiosyncratic volatility, as that suggests that total volatility analyses would yield different results.
} 
observed in the sample ending in 1997 is clearly a temporary "hump" in volatility at the turn of the Millennium, a point also observed by Brandt et al. (2010). Volatility since the start of 2004 seems to accord with historical norms. There appear to be three main episodes of abnormally high volatility: the 1974 OPEC oil crisis, an outlier in the fourth quarter of 1987 associated with the crash in October, and the aberrant behavior in volatility associated with the tech-bubble. The first two episodes and the "hump" at the end of the Millennium differ both in the length of the episode and magnitude of volatility elevation. Because the "hump" lasted for about a decade and the variation in volatility during this decade was particularly acute it seems clear that the significance of a particular proxy would predominantly depend on its ability to explain volatility behavior during this "hump” period. Further, it is not clear why the different explanations provided in the literature (age of a firm, growth options, etc.) would be an important characteristic for systematic events such as the 1974 OPEC oil crises, and the 1987 crash. We thus pay particular attention to the run-up and subsequent drop in volatility around this episode in our empirical analysis. ${ }^{3}$

We undertake an empirical study of volatility using both cross-sectional and timeseries tests using weighted-average predictor variables. ${ }^{4}$ Our point is simple; most of the papers of Table 1 claim to provide an explanation for the volatility trend in the market. However, most of the papers listed in Table 1 only provide cross-sectional evidence that their chosen proxy is correlated with volatility. The common reason for not directly testing correlation between the trend in volatility and the trend in the proxy associated

\footnotetext{
${ }^{3}$ We note that understanding volatility changes by analyzing the period in which it changed the most was also the approach taken by Schwert (2002).

${ }^{4}$ We use the term cross-section somewhat loosely. We refer to our panel data firm-level analysis, which pools both time-series and cross-sectional data, a cross-sectional analysis to distinguish it from our pure time-series analysis that uses only the time series of cross-sectional value-weighted variables.
} 
with the explanation is that it is difficult, if not impossible, to directly prove or disprove a theory based on a single trended series (see for example, Brandt et al. (2010) Section 4.1). However we claim differently; without a direct test that relates the chosen proxy to the trend in volatility, the relevance of the explanation to the overall trend in volatility remains unclear. If the explanation is to have "a first-order effect" on the trend in average volatility levels, it should be correlated with it. Notably, there are studies that focus predominantly on analyzing the trend. For example, Cao et al. (2008) present strong evidence that the average market-to-book ratio is correlated with the trend in volatility. Unfortunately, these authors do not provide any analysis on the relevance of the market to book ratio for explaining cross-sectional variation in volatility levels across firms.

To motivate the joint focus on the time-series and panel suppose that a particular firm characteristic is positively related to firm-level volatility. A systematic increase in that characteristic or an increase in the market capitalization of firms with high values of that characteristic will result in higher average volatility. For example, if low priced firms tend to be more volatile because of retail investors trading of these stocks, then a systematic decrease in share prices will mean that the relative importance of low priced shares in the market has increased, and that should lead to an increase in the average volatility in the market. Thus, a systematic change in share price levels should be correlated with the trend in volatility. It will also mean that a share's price will have cross-sectional explanatory power when comparing volatility levels across firms. Virtually all current theoretical arguments that are provided for the studies in Table 1 lend themselves to explanations about the difference in volatility levels between firms just as well as they do for a time-series explanation for the trend in the average level of 
volatility in the market. Thus, by looking at these two dimensions jointly we provide a deeper analysis of the usefulness of the different explanations and their proxies. Obviously we need both these features for a plausible explanation for the behavior of volatility: the variable must explain volatility across different firms and the variable must also have changed through time. A variable that explains much in the cross-section but has not changed through time is of limited usefulness. Only a time-series analysis based on value-weighted averages of the variable and volatility can identify variation through time. On the other hand by focusing exclusively on the time-series evidence we lose a tremendous amount of useful information because we have relatively few observations (slightly over 125 quarterly observations as opposed to tens of thousands of firmquarters), and the time-series variables exhibit a high degree of correlation. Although some previous research has focused exclusively on either the cross-section (Xu and Malikiel, 2003; Pastor and Versonesi, 2003; Bennett and Sias, 2006; Brandt et al., 2010) or the time series (Cao et al., 2008), there are studies that consider both types of analyses (Wei and Zhang, 2006; Fink et al., 2006; Rajgopal and Venkatachalam, 2010; Brown and Kapadia, 2007; Irvine and Pontiff, 2009). However, those studies that do include timeseries regressions only include few variables. ${ }^{5}$

The studies of Table 1 use different sample sizes and different volatility (or idiosyncratic volatility) measures. This raises the question of whether it is possible to conduct a fair horse race between the different proxies. To resolve this issue, we start our study by conducting an in-depth analysis of the different measures and samples and show that differences in these aspects between studies are small, insignificant, and do not affect

\footnotetext{
${ }^{5}$ Rajgopal and Venkatachalam (2010) is the only paper to conduct a multivariate time-series with more than three variables (in their Table 4). However, the variables included in their analysis (except for marketto-book) are not those variables that are associated with the other explanations provided in the literature.
} 
our results. Further, we show that the importance of the different proxies for the trend are similar whether we include lagged volatility in the regression or not, suggesting that the results of this study are robust.

Our main empirical results can be summarized as follows:

1) Cross section - turnover and low price are the most robust variables in the crosssection (except for lag volatility). Other variables that have cross sectional explanatory power include: a firm's age, dividend dummy, volatility in fundamentals, and Nasdaq classification. Important, the market-to-book ratio has no cross-sectional explanatory power which questions the relevance of the managerial growth-options explanation (Cao et al., 2008).

2) Time series - Many of the variables proposed in past studies fail to provide any contribution to the trend. These variables are associated with the following explanations: speculative episodes associated with low priced stocks (Brandt et al., 2010), institutional ownership (Malkiel and $\mathrm{Xu}, 2003$ ), and volatility in fundamentals (Wei and Zhang, 2006; Irvine and Pontiff, 2009). Interestingly, the market-to-book ratio is the single strongest variable in the time-series regressions (other than lagged volatility).

3) Overall conclusion - The variables that have cross-sectional explanatory power and also track average volatility over time (once lagged volatility is included) are Nasdaq classification (Schwertz, 2002); the age of the firm (Fink et al., 2006; Brown and Kapadia, 2007); dividend policy (Pastor and Veronesi, 2003); and turnover. A univariate time-series regression with any of these variables and lagged volatility yields somewhat similar results with an adjusted R-squared in 
the range 0.41-0.47. However, these variables are not able to explain the trend in the average volatility level in the pre-1995 period. Thus, it seems that the explanations are not able to describe the trend over the three decades, but rather these variables do a particularly good job in tracking the average level of volatility level during the "hump” period.

The remainder of the paper proceeds as follows. Section II provides an empirical analysis on the differences between different volatility measures. In Section III we describe our data and the proxies that we use to compare past studies. Section IV presents our crosssectional panel regression results and Section V the time-series results. We conclude in Section VI.

\section{Volatility}

\subsection{Different volatility measures}

As can be seen from Table 1, past studies addressing the volatility trend used a variety of volatility measures. Some studies analyzed total volatility (Schwert, 2002; Wei and Zhang, 2006), some analyzed the market model residual (Pastor and Veronesi, 2003), some analyzed the residual of a four-factor model (Xu and Malkiel, 2003; Brown and Kapadia, 2007), some analyzed the Campbell et al. (2001) market adjusted volatility measure (Wei and Zhang, 2007; Irvine and Pontiff, 2009), and some analyzed the industry adjusted Campbell et al. (2001) measure (Brandt et al., 2010; Bennett and Sias, 2006; Fink et al., 2006; Cao et. al, 2008). Most of the studies claim that their results are robust to other volatility specifications and usually provide a short discussion of why they used their particular measure. However, none of the studies engage in an empirical 
analysis to assess the difference between the different volatility measures. This is important because if there is no real difference between the different measures, then it is not clear why we should go through the process of developing these measures in the first place instead of simply analyzing total volatility levels as done in Schwert (2002).

We note that although Campbell et al. (2001) find an upward trend in average idiosyncratic volatility they do not uncover such a trend in the volatility of aggregate stock market returns, which suggests that the trend in idiosyncratic volatility should closely track the trend in total volatility. Indeed, as can be seen from Figure 1, the pattern of the volatility measure, the excess industry volatility measure, and the sum of squared errors of the four-factor model are similar. The difference between the different measures is in their magnitude: volatility is higher than excess industry volatility; and the excess industry volatility is higher than the sum of squared errors of the four-factor model. This is rather intuitive because the four-factor model allows for time-varying betas. An important observation is the outlier in the $4^{\text {th }}$ quarter of 1987 . Because the one day event on October 1987 was market-wide, the Campbell et al. (2001) excess industry volatility measure is smaller than the sum of squared errors of the four-factor model. This is because the-four factor model estimation is done quarterly based on daily returns, so the market-wide drop in prices on a single day only marginally contributes to the beta calculations of the model; however, as in the Campbell et al. (2001) methodology the residuals are calculated daily, the excess industry volatility is relatively small if there is a one day market-wide drop in prices. Thus, it is important to note that the correlation between the different measures is affected by this outlier - as this one day event changes the relative magnitude ordering between the three measures. 


\subsection{Sample size and correlations}

In this study we employ a large set of conditioning variables to study the volatility trend during the years 1972-2005. A limitation of using many conditioning variables is that the sample size is reduced because some firms do not have the necessary data to compute the conditional variables (namely data from either Compustat or Thomson Financial). As we want to address the trend in the population (all NYSE-AMEX-Nasdaq traded firms), we must mitigate concerns that the results of this paper are sample specific. $^{6}$

Table 2 provides cross-section and time-series correlations of four different measures of volatility across our sample (246,607 firm-quarter observations) and across the population (814,542 firm-quarter observations). In Panel A below the diagonal, we provide the cross-section correlation and rank Spearman correlation between pair-wise volatility measures in a given quarter. The standard deviation of the correlation across the quarters is provided in parenthesis. Above the diagonal, the population pair-wise crosssection correlations are provided. There are two major things to take from Panel A. First, all measures are highly correlated. In particular in our sample, volatility has a correlation of above $67 \%$ with the three idiosyncratic volatility measures. This is an extremely high correlation for such a large sample, and it broadly suggests that cross-sectional regression results with any one of these measures should be rather similar. The correlations between

\footnotetext{
${ }^{6}$ In general, we believe that differences in samples across the studies of Table 1 are of minimal concern. In broad terms, it is fair to say that most of the studies in Table 1 and our study include at least $70 \%$ of the market value of firms during those three decades. However, to make sure that this is indeed the case, we replicate Cao et al. (2008) with the full sample of firms (their original work does not include the financial services sector as these firms are theoretically less linked to growth options) and find that their results are robust for the full sample of firms. The only two studies which rely on a much smaller sample size are Xu and Malkiel (2003) and Rajgopal and Venkatachalam (2010). We believe that samples of these latter two studies are not necessarily representative of the overall US market.
} 
the measures in the population are even higher. Second, the lowest pair-wise correlation is between the excess industry measure and the four-factor measure, with a correlation of 0.42 in our sample (0.67 in the population). Though even this correlation is rather high for such a large sample, it is interesting that the correlation between two different kind of idiosyncratic measures is lower than the correlations between the total volatility measure and the different idiosyncratic measures.

In Panel B, we provide average measures across the sample period. Thus, since we have 128 quarters, each measure is based on 128 observations. These are purely timeseries correlations as there is one observation per quarter. Given that we know that 1987q4 is an outlier, in parenthesis we provide correlation across 127 quarters, excluding this quarter. Below the diagonal we provide value-weighted measures, while above the diagonal we provide equal-weighted measures. We observe two things. First, valueweighted measures are highly correlated. In particular, the correlations between the volatility-sample measure and all the other volatility measures are above 0.92 . Further, the correlations uniformly increase once we exclude 1987q4 (the correlation between excess industry and four-factors increase from 0.83 to 0.92$)$. These correlations do not seem to vary depending on the sample size. Second, equal-weighted measures have a relatively low correlation. Also, for equal-weighted measures the sample size matters. Take for example the correlation between excess market and excess industry. In our sample, the correlation is 0.999 , however; in the population it drops to 0.66. Even if we take the correlation between the same measure across the sample and population, the correlation is not high given the small number of observations (for example, for the excess market measure the correlation is 0.80). This suggests that results concerning 
equal-weighted measures will depend on the type of dependent variable we employ. Obviously, when the correlation between measures is not very high and the sample is small, the results cannot be robust and we therefore do not analyze equal-weighted measures in this paper. To conserve space we only report our total volatility analysis, but the results using the other three idiosyncratic volatility measures are qualitatively similar and are available on request. We find that the ranking of the three or four most important conditioning variables (in terms of statistical significance) in both the cross-sectional and time-series analyses is the same across the different measures. ${ }^{7}$

\section{Conditioning variables}

Because we are primarily interested in explaining the last decade of unusual volatility we select a wide range of potential explanatory variables. Because some relevant variables are only available for a short time period we face a trade-off between having a very long sample with fewer variables or many variables over a shorter sample. To suitably balance these two concerns we use only data from Compustat, CRSP and Thomson Financial. As some of the explanations provided in the literature are highly overlapping (in the empirical sense), our guideline for selecting between alternative variables is to choose the variable that covers the largest number of firms. For example, we include volatility in profitability measures (Wei and Zhang, 2006) rather than cash flow volatility measures (Irvine and Pontiff, 2009) because it has fewer missing observations. We also omit variables that are based on very limited data sets (e.g., I/B/E/S or Zacks data set). To construct a volatility in profitability measure (Wei and

\footnotetext{
${ }^{7}$ We do note that there are some interesting differences beyond this. For example, the cross sectional regressions on volatility and excess industry volatility yield higher R-squared than those of the idiosyncratic volatility from a four-factor model.
} 
Zhang, 2006), we require financial information for the previous 12 quarters. As Compustat provides quarterly information starting 1970, our data includes all NYSE, AMEX and Nasdaq firms for which we have no missing values during the period 1973q1 to 2005q1. In total, we have 246,607 firm-quarter observations.

\subsection{Nasdaq}

Schwert (2002) documents that Nasdaq firms have shown a dramatic increase in volatility during the mid-late 90s. We therefore employ a Nasdaq indicator, which equals 1 if the firm is traded on Nasdaq, and zero otherwise.

\subsection{Dividends}

Pastor and Veronesi (2003) and Rubin and Smith (2009) show that firms that do not pay dividends have much more volatile returns. In fact, both studies show that dividend policy is the most significant determinant of volatility in the cross-section. We follow these studies and employ a No dividend indicator, which equals 1 if the firm did not pay a dividend during the quarter.

\subsection{Age}

Fink et al. (2006) argue that there has been a substantial increase in the fraction of young firms contemporaneously with the increase in idiosyncratic volatility. They focus primarily on the average age of a firm at the time of its IPO. They argue that in recent decades, and especially in the late 1990s, younger firms became public and coupled with the significant increase in the number of firms going public, it lead to a steady increase in 
idiosyncratic risk. Theoretically, the idea of age affecting volatility is supported by Pastor and Veronesi (2003) who claim that investors learn about firm's profitability over time. In a different study, Brown and Kapadia (2007) claim that it is not age itself that is important for volatility, but rather, firms that have been listed in more recent years are fundamentally riskier. ${ }^{8}$ It is important in their analysis that firms from more recent IPO vintages exhibit persistently higher idiosyncratic risk than firms from earlier vintages. They claim that if firm age itself is important for volatility we should have observed a reduction in a firm's volatility over time, as it ages. However, they do not find evidence of a meaningful or consistent decline in volatility for IPO listing vintage groups over time. An alternative explanation for this empirical observation is that the marginal contribution of a single year to the age of a firm is important only in the first few years post-IPO, when the investing public is not familiar with the company. Because Brown and Kapadia (2007) partition firms to 10 year segments based on IPO vintage, they may miss the resolution of the age variable where it matters most, i.e. when firms are very young. Further, as we observe in Figure 1, most of the variation in volatility occurs during the years 1995-2004. During that period the number of new listed firms increased (and then decreased) dramatically so both the average firm age and the value of the 19952004 IPO vintage will be highly correlated. To include the finding of both papers, our Age variable is the number of years since the firm appears on CRSP and we Winsorize our age variable at 30 years, as the marginal effect of a year for older firms is limited. ${ }^{9}$

\footnotetext{
${ }^{8}$ Empirically, Brown and Kapadia (2007) show that 5 dummy variables of IPO vintage decades drive out age in the cross-section.

${ }^{9}$ Note that Fink et al. (2006) and Brown and Kapdia (2007) measure age as the year of either founding or incorporation, while Pastor and Veronesi (2003) measure age as the number of years since the firm appears on CRSP. We find that the two measures are highly correlated (0.89), and that the way age is measured does not alter the results.
} 


\subsection{Earnings and earnings volatility}

Wei and Zhang (2006) claim that changes in earnings fundamentals may be the reason behind the increase in idiosyncratic volatility, which Irvine and Pontiff (2009) claim is attributed to more intense economy-wide competition. Both papers produce somewhat different proxies for volatility in fundamental cash flow; however, they both rely on data from the 12 previous quarters. Because Wei and Zhang’s (2006) measure has fewer missing observations we follow their methodology. They show that stock return volatility is negatively related to the return on equity (ROE) and positively related to the volatility of profitability (VOLP). We follow Wei and Zhang (2006) in calculating VOLP based on the previous 12 quarters ROEs, and Winsorize the firm-level ROE observation at -0.5 and 0.5 .

\subsection{Share price}

Brandt et al. (2010) find a strong cross-sectional relation between low priced stock and idiosyncratic volatility. They suggest that volatility tends to elevate during episodes of euphoric bull markets with record price-fundamental multiples. They suggest that during these speculative episodes investors are particularly attracted to low priced stocks, which leads to a strong correlation between share price and return volatility. We thus use a Low price indicator for firms whose price is less than $\$ 10$ at the end of the quarter. 


\subsection{Growth options}

Cao et al. (2008) establish a theoretical link between idiosyncratic risk and growth options available to managers. While they motivate their analysis by manager's desire to increase the value of the equity by taking more idiosyncratic risk when these options are available; empirically, it would be hard to distinguish between a managerial growth option explanation and a simple change in long term growth (Xu and Malkiel, 2003). To illustrate this point, consider the market-to-book ratio, which is Cao et al.’s (2008) preferred proxy for managerial growth options. According to the Gordon growth model, the value of a share is given by

$$
P_{0}=\frac{d_{0}(1+g)}{r_{e}-g},
$$

where $d_{0}$ is the current dividend, $r_{e}$ is the required return on equity and $g$ the expected growth rate of the firm's dividends. Since dividends paid can be represented as the return on equity multiplied by the payout ratio, the market-to-book ratio can be represented as

$$
\frac{P_{0}}{B_{0}}=\frac{R O E \times \text { payout ratio } \times(1+g)}{r_{e}-g}
$$

where $B_{0}$ is the book value of equity, and $R O E$ is net income divided by equity. Even if we assume a fixed $r_{e}$ (i.e., as we are focusing our attention on idiosyncratic volatility), we must be cautious in interpreting what market-to-book is proxying for, as it is a combination of dividend policy (payout ratio), profitability (ROE), and expectations on growth (or alternatively availability of growth options). Unfortunately the link between the theoretical motivation (i.e., managerial growth options) and the empirical support becomes unclear when market-to-book is used to track changes in volatility levels. Further, as capital expenditure, an alternative proxy used by Cao et al. (2008) for growth 
options, does not track volatility well, it is hard to interpret these results. ${ }^{10}$ In our analysis we use the market-to-book measure (Maba) and calculate it following Appendix B of Cao et al. (2008).

\subsection{Regulated industries}

One possible explanation for the change in volatility may be changes in the composition of industries, which is referred to in Bennett and Sias (2006) and Wang (2010). While to some extent this change is captured by Nasdaq, we also employ a Not regulated indicator for firms that are classified in non-regulated industries (first SIC digit is not 4 or 6). We choose this variable because regulated firms are significantly less volatile than non-regulated firms.

\subsection{Institutional ownership}

Another possible explanation for the change in volatility may be the increase in the level of institutional ownership that has occurred in the last decade. Xu and Malkiel (2003) claim that institutions may have common sentiments and their interpretation of news may lead to similar buy/sell decisions. If that is the case, when institutions hold a larger fraction of the market, they may contribute to volatility. ${ }^{11}$ Institutions is defined as

\footnotetext{
${ }^{10}$ We use capital expenditure both in the cross-section and time-series. Since capital expenditure is missing for many firms, using it in the analysis reduces the sample and we do not report the results here. However, capital expenditure is not significant in the cross-section and the time-series (once lagged volatility is included).

${ }^{11}$ A related but opposite view is that the broadening of the investor base may actually lead to a reduction in volatility. This would be in line with the recent of evidence of Umutlu et al. (2010) that the increasing degree of financial liberalization lead to a broader investor base and causes a reduction in the total volatility of stock returns.
} 
the fraction of institutional ownership of the firm's share at the end of the quarter. ${ }^{12}$

\subsection{Turnover}

We supplement the variables discussed above, which have all been considered in the literature, with an additional variable that has been ignored but is nonetheless crucial for studying volatility: turnover. The relationship between trading volume (or turnover) and price volatility is well documented. In 1987, Karpoff (1987) discusses 19 articles studying this empirical link. The information flow induced volume-volatility link has been motivated theoretically by Epps and Epps (1976), Tauchen and Pitts (1983), Admati and Pfleiderer (1988) and Foster and Viswanathan (1990). Some of the more recent empirical studies include Lamoureux and Lastrapes (1994), Richardson and Smith (1994), Foster and Viswanathan (1995), Fleming, Kirby and Ostdiek (2006), and Chuang et al. (2009). Curiously, despite the rich theoretical and empirical literature on the role of trading volume on volatility it has been essentially ignored in the debate about idiosyncratic volatility at the turn of the Millennium. This omission is important because the common explanatory variables are correlated with turnover, and their significance may be due to an omitted variables bias. In fact the only two papers in this literature that control for turnover in the analysis are Brown and Kapadia (2007) and Brandt et al. (2010) but they do so only in the cross-section. We rectify this oversight and include turnover as a putative explanatory variable, alleviating concerns that previous results may

\footnotetext{
12 Our data on the level of institutional ownership starts in 1980. To avoid exclusion of the period prior to 1980, we set the institutional variable to zero during those years. To mitigate the bias from this procedure (because there were institutional stockholders prior to 1980), we include a dummy variable in both the time-series and cross-sections regressions that takes the value unity in the period of unobserved institutional ownership. We also re-run all analyses of the paper using only post-1979 data. As there is no qualitative difference in the cross-section and post-1979 analyses we do not report it, but it is available from the authors.
} 
be resulting from an omitted variables bias. ${ }^{13}$ We define the variable Turnover as the average monthly turnover in the firm's stock in a given quarter. ${ }^{14}$

\section{Cross-sectional analysis}

We start our analysis of the cross-sectional determinants of volatility using a panel regression approach. As noted above, we are particularly interested in understanding the curious behavior in the late 1990s. We therefore partition our sample into two sub-periods: the period before 1995 and the period after 1994 . We choose to partition the sample at the start of 1995 because it appears from Figure 1 to be around the time where the "hump" begins. Also, our sample ends in the first quarter 2005, which gives exactly 10 years of data in the post-1994 era. ${ }^{15}$

Table 4 presents some descriptive statistics of the dependent and independent variables during the two sub-periods. We observe that quarterly volatility levels increased from a median of 3\% in the pre-1995 period to a median of 5\% in the post-1994 period. Interestingly, there is no apparent change in the standard deviation in volatility between the two sub-periods. Other changes in firms' characteristics are also observed in the table. Turnover levels have more than doubled, increasing from a median of $34 \%$ to a median

\footnotetext{
${ }^{13}$ We also note that some other explanatory variables can be indirectly motivated by turnover. For example, Campbell et al. (2001) discuss the contemporaneous increase in the level of institutional ownership and idiosyncratic volatility in terms of common trading behavior and the increase in day trading as potential explanations. Similarly, firms that have more uncertainty about future profitability tend to have higher turnover levels since there is more heterogeneity in beliefs about their future performance (Harris and Raviv, 1993; Kraus and Smith, 1996). Therefore, we can also motivate turnover as a control variable.

${ }^{14}$ In addition, to make sure that turnover is not simply proxing for liquidity (which may be a component of stock return as in Amihud (2002) and Acharya and Pedersen (2005)), we have also constructed the Amihud (2002) illiquidity measure. The measure and its affect in the cross-sectional analysis are discussed in footnote 16.

${ }^{15}$ Varying somewhat (i.e., a year or two) the quarter we partition on does not materially affect our results. By also analyzing each sub-period separately, we are effectively following the approach of Schwert (2002) who also paid particular attention to the period in which the unusual behavior of volatility occurred.
} 
of $71 \%$. The median age (recall that we Winsorized at 30) had decreased from 14.3 years to 11.1 years. Thus it appears that the increase in IPO activity reduced the average age of listed firms. Maba has also increased by about 20\% from a median of 1.13 in the pre1995 period to a median of 1.33 in the post-1994 period. There are also clearly evident changes in ROE and VOLP. There seems to be dramatically more variation in these two variables in the post-1994 period as compared with the pre-1995 period. Finally, the increase in institutional ownership is substantial, increasing from $17.62 \%$ in the early period to a level of $40.26 \%$ in the post-1994 period.

Regarding our indicator variables, we observe that the number of Nasdaq traded stocks has increased dramatically. While these represent only $24 \%$ of sample firms in the pre-1995 period, they constitute 53\% in the post-1994 period. Similar to Fama and French's (2001) observation, we find that non-dividend paying firms constitute $60 \%$ of the sample firms in the post-1994 period. There are also almost twice as many low priced stocks in the post-1994 period as in the pre-1995 period, while the percentage of nonregulated firms seems to have decreased somewhat over time.

Taken together, the summary statistics indicates that all of the characteristics, with the possible exception of the number of non-regulated firms, have changed dramatically. Further, the directions of the changes in all the variables, except for the number of regulated firms, are in the right direction to provide a reasonable explanation for the increase in volatility.

We next turn to the correlation coefficients between the different explanatory variables used in the study. We calculate the correlation coefficients for the pre-1995 and post-1994 period separately, and present the average and standard deviation of 
correlations for each of the sub-samples. The correlations are calculated every quarter and standard deviations (in parentheses) are calculated across the quarters in the subsample. Below the diagonal we present averages of correlation for each pair of variables in the pre-1995 period, while above the diagonal we repeat the calculation for the post1994 period. In Table 5 we can observe that for both sub-periods, the pair-wise correlation coefficients have predominantly the same sign in the two sub-samples; however the magnitude of the correlations did change in a few cases. In particular, when we look at the volatility row and column, the signs of the correlation is always the same; however, there are sizeable changes for some of the pairs. The non-regulated dummy positive correlation with volatility has increased in the post-1994 period compared with the pre-1995 period, suggesting that non-regulated firms have become more volatile over time. We observe a similar pattern among Nasdaq firms. Interestingly, the market-tobook ratio is essentially not correlated with volatility in the pre-1995 period, but has a moderate correlation with volatility in the post-1995 period. Finally, the high absolute correlation of turnover, age, the no dividend dummy, and VOLP with volatility seem to be a rather persistent attribute of the data. Thus, even though we had observed major changes in many of the explanatory variables over time, we learn that the variables that are highly correlated with volatility (in absolute value) are rather stable through time. ${ }^{16}$

Table 6 provides cross-sectional regressions for the two sub-periods. We normalize all our variables so the coefficients can be interpreted as the number of standard deviations change in response to a one standard deviation change in the independent variable. Because the dependent volatility is heavily skewed (the skewness

\footnotetext{
${ }^{16}$ Note that because institutional ownership is truncated at 1980 because of lack of data; the rank Spearman and regular correlations are calculated based on 1980q1-1994q4 data in the pre-1995 sub sample. See also footnote 10 .
} 
statistic is 82.66) we use the natural log of volatility as the dependent variable. Apart from the explanatory variables described in the previous section, we also control for Size (the market value of the firm's equity). Because market value is also skewed (a skewness coefficient of 16.58) we also take its log. Because volatility is very persistent we include the lag of the dependent variable (Lag volatility) as an independent variable to ensure our standard errors are valid. All independent variables are from the previous quarter (i.e., lagged), except for turnover, which is a flow variable. ${ }^{17}$ We consider a range of regression specifications. In specifications (1a), (2a), and (3a) we use firm and quarter fixed-effect regressions, while in specifications (2a), (2b), and (2c), we follow Petersen (2009) and apply the double clustered standard errors, which correct for both time and firm dependency.

A number of key results emerge from Table 6. Although the statistical significance of the coefficients varies slightly between specifications, both specifications provide similar interpretations. While this result may not be terribly surprising given that our sample is so large, we stress that the results suggest that the fixed-effect regression may be driven by cross-sectional differences rather than by changes through time. ${ }^{18}$ Further, the results in both sub-periods are quite similar, suggesting that the importance of the variables for explaining volatility in the cross-section has not changed dramatically over time. The most important explanatory variable is lagged volatility, which explains about $35 \%$ of the variation in volatility in the fixed-effect specifications and about $60 \%$ of the variation in the clustered errors specifications. Also, the coefficient of lagged

\footnotetext{
${ }^{17}$ The qualitative nature of the results is not affected by using the contemporaneous explanatory variables.

18 Though the fixed-effect specification of Table 5 provides slightly different estimates, the sign and significance of the coefficients yield essentially the same results as the double clustered or Fama-McBeth (1973) specifications (not provided, but available from the authors on request).
} 
volatility is more statistically significant than any other coefficient. Turnover is the second most robust variable. ${ }^{19}$ It accounts for about $15-20 \%$ of the variation depending on the time and specification. The third most significant coefficient is the low price indicator, which accounts for an average of $10 \%$ of the variation in volatility. Size also accounts for an average of $10 \%$ of the variation in volatility, but its coefficient is much less significant than that of low price, turnover or lagged volatility. The coefficients of age, no dividend, and Nasdaq are also significant (with the expected sign) but seem to jointly explain less than $10 \%$ of the variation in volatility. Also, the Nasdaq coefficient is much more significant in the post-1994 period than in the pre-1995 period. Volatility in fundamentals, which is represented by the coefficients of ROE and VOLP, also explains some of the variation in volatility, and both coefficients are very significant (with the expected sign). As one may expect, non-regulated firms seem to exhibit a somewhat higher volatility level, but the coefficient is not significant in the pre-1995 period when using the fixed-effect specification. Finally, in both sub-periods, the coefficient of Maba is negative and statistically significant in the fixed-effect specifications, and is positive but insignificant in the clustered errors specifications. These results indicate that marketto-book is not an important variable for explaining firm-level volatility in the crosssection. We also find that institutional ownership is negatively correlated with volatility,

\footnotetext{
${ }^{19}$ We also ran Table 6 with Amihud (2002) illiquidity measure, defined as the absolute daily return divided by the daily volume. We used this measure in both specification (clustered and firm fixed-effects) and results were rather similar. For example in the full sample with double clustering we got that (1) the coefficient on the Amihud measure was positive (t-stat of 7.14) and the coefficient of turnover increased significantly (t-stat of 22.76). (2) In a regression with all variables excluding turnover - the Amihud measure is marginally significant (t-stat of 1.89). Overall, because the significance of the Amihud measure is much lower than turnover, these results suggest that liquidity is not a major determinant of volatility, but other related volume reasons as discussed are important in explaining volatility.
} 
which is counter to the small-sample S\&P 500 results of Xu and Malkiel (2003). ${ }^{20}$

Summarizing the results of Tables 4, 5, and 6, we find that the relation between the different variables and firm-level volatility is persistent across the different methodological approaches and different time periods. We find that most of the explanations proposed in the literature provide some explanatory power over and above lagged volatility; though, the coefficient on lagged volatility is by far the most significant. We find that turnover is the second most robust variable and the low price indicator is the third most robust variable. Other variables that are consistent with their respective explanations include: age, no dividend, Nasdaq, VOLP, ROE, and notregulated. We find that the coefficients on Maba and institutions are either negatively significant or not significant, which is counter to the explanations provided by Cao et al. (2008) and Xu and Malkiel (2003) respectively.

Note that although the cross-sectional analysis indicates the importance of the different variables in determining firm-level volatility, it is unable to identify those variables that are responsible for the time-series behavior of volatility. Most of the variables provide similar explanatory power in both sub-samples, and both have changed over time. Further, as there is a high correlation between the different explanations, a careful time-series analysis is necessary.

\section{Time-series analysis}

It is important to note that panel-regression results are mainly driven by cross-

\footnotetext{
${ }^{20}$ We note that Xu and Malkiel (2003) only controlled for size in their cross-sectional analysis. To make sure that the negative coefficient of institutions is not caused because of the zero value in the pre-1980 years, we rerun the first sub sample period excluding the observation that predate 1980 . The point estimate on institutions' coefficient is similar in magnitude and sign.
} 
sectional variation and this cross-sectional variation will also tend to appear in firm fixedeffect regressions. This is because the number of cross-sectional observations is very large relative to the number of time-series observations. This suggests that although a variable may appear statistically significant in the cross-sectional regression it does not necessarily have any explanatory power for the time-series variation in average volatility.

Our approach therefore is to track changes in aggregate volatility with changes in aggregate measures. Previous studies following this approach (Fink et al., 2006; Wei and Zhang, 2006; Brown and Kapadia, 2007; Cao et al., 2008; Irvine and Pontiff, 2009) are almost always univariate in nature. The content of such a univariate analysis is also contained in the simple time-series plots of the underlying variables. Furthermore, given the high correlation between the alternative conditioning variables we must be cautious in interpreting the results because of potential omitted variables bias. In contrast, we employ a multivariate analysis and compare these results with the univariate estimates.

We aggregate all our variables following the Campbell et al. (2001) methodology. Value-weighted measures are computed as

$$
V W_{t}=\sum_{i=1}^{N_{t}} w_{i t} m_{i t},
$$

where $V W_{t}$ is the aggregated value-weighted measure at time $t, w_{i t}$ is the weight of firm $i$ at the end of quarter $t-1$ (measured in terms of market value), $m_{i t}$ is the measure of firm $i$ calculated at the end of quarter $t$ or during quarter $t$ depending of the type of measure (i.e., stock or flow), and $N_{t}$ denotes the number of firms at time $t$. The indicator variables we employed in the cross-section analysis lend themselves to easy interpretation when value-weighted. Nasdaq translates to the market portion (percentage) attributed to Nasdaq 
traded firms. The no dividend indicator translates to the market portion (percentage) attributed to non-dividend paying firms; the low price indicator translates to the market portion (percentage) of firms whose price is less than $\$ 10$; and the not regulated indicator translates to the market portion (percentage) of firms classified to non-regulated industries.

\subsection{Time-series evidence}

In Panel A of Table 7, we compute the sample mean and standard deviation for the value-weighted sample in the pre-1995 and post-1994 sample periods. Similarly to the results in the cross-section, the average level of volatility is much higher in the post1994 data-being nearly twice the size. We observe that the level of many of the variables differ dramatically between the earlier periods, which is similar to the crosssectional results reported in Table 4. The large change occurs for all variables except age, ROE, and the not regulated and low price dummies. The absence of a dramatic change in the market value of low priced stock is particularly interesting (it increased from $1.86 \%$ to $2.06 \%$ ) because Table 3 revealed that the fraction of low priced stocks had increased dramatically (from $27 \%$ of the sample in the pre- 1995 period to $47 \%$ of the sample in the post-1994 period). This suggests that the speculative episode explanation may not have much explanatory power for the trend in value-weighted volatility.

Figure 1 plots the time series of value-weighted volatility measures. It is clearly apparent that the volatility trend documented by Campbell et al. (2001), whose data terminated in 1999, was actually a "hump” around the turn of the Millennium. In Figure 2 we plot the time-series of each value-weighted average of the ten conditioning variables 
of interest. The most striking observations are the high correlation between many of the variables. This is born out by the sample correlation of the value-weighted variables in Panel B of Table 7. While the cross-sectional correlations between the variables are not terribly large (in absolute value), we do observe high correlations between many of the value-weighted variables (in absolute value). The correlation between the different explanatory variables and turnover is particularly high. Except for ROE and low price, turnover has a correlation of about 0.7 or above (in absolute value) with any other explanatory variables. Most relevant for the attempt to explain the volatility "hump" is the peak around 2000-2001 evident in Figure 2 in the time-series of Turnover, Maba, NASDAQ, no dividend, and age (where, we can observe a corresponding dump in 20002001) variables. This high correlation between the different explanatory variables calls for caution in interpreting the results from time-series tests, as it raises concerns about both multicollinearity and omitted variables bias. Figures 1 and 2 also clearly identify the radically different behavior of many aspects of the stock market in the late 1990s and early part of the new Millennium.

In Table 8 we report the results of a regression of value-weighted average volatility on a range of conditioning variables. ${ }^{21}$ We first run univariate regressions on each of the ten explanatory variables and then a multivariate regression using all variables jointly. The Durbin-Watson statistic is recorded in the last row of the table and all models, except specification (11), exhibit strong positive serial correlation (i.e. the DW statistics are less than 2), suggesting miss-specification. ${ }^{22}$ To account for this serial

\footnotetext{
${ }^{21}$ As noted above all stock variables are lagged one-quarter. The results reported are basically unchanged if one runs the regression with the contemporaneous variables, which is not surprising since all of the stock variables are highly persistent.

${ }^{22}$ The evidence of serial correlation is similar when we use the Ljung-Box test also.
} 
correlation we compute the standard errors following Newey and West (1987) using 3 lags (recall we are using quarterly observations). We report three adjusted R-squared in Table 8 (and later also in Table 9) - the first adjusted R-squared is for the same specification regression if we were to run the regression only for the pre-1995 period, the second adjusted R-squared is for the same specification regression if we were to run the regression only for the post-1994 period, while the third R-squared is that of the full sample, whose estimators are tabulated. ${ }^{23}$ The fit of the univariate regressions as measured by adjusted R-squared varies substantially between sub periods and across variables. While the variables explanatory power is very low for the pre-1995 period, several of the variables are quite successful in explaining volatility in the post-1994 period. The best fit for the pre-1995 years is provided by the Low price (adjusted Rsquared of 4.84\%) and not regulated (adjusted R-squared of 3.85\%) - however even these fits are rather low. For the pre-1995 years we learn that for some specification, the adjusted R-squared (no dividend, Nasdaq, VOLP, ROE) are actually negative, suggesting that the variables do not provide any explanatory power for the volatility trend in that period. As we conjectured, the variables that best fit the trend do so mostly because of the post-1994 period. The best fit is Maba, which generates an adjusted R-squared above 36 percent for the full sample. This result is similar to that of Cao et al. (2008). Three other variables do a moderately good job in explaining the trend over the entire period: turnover, age and no dividend, whose regressions have an adjusted R-squared of 23-25 percent. Other variables have a much lower adjusted R-squared and/or produce results

\footnotetext{
${ }^{23}$ To preserve space we provide only Adj. R-squared for the sub-period regressions. The coefficients of most variables in the pre-1995 period are insignificant, while the coefficient of the variables in the post1994 period tend to provide similar interpretation as the full sample results provide. The only two significant coefficients in the pre-1995 period in the univariate regressions are those of not regulated and Low price, which are significant at the $5 \%$.
} 
that are inconsistent with their theoretical motivation. ROE is able to explain only 5 percent of the variation and has a positive and statistically significant coefficient, which is counter to the explanation that higher ROEs should reduce volatility. VOLP is only marginally significant with $t$-statistic less than 2 . Similarly, the value of non-regulated firms is negatively correlated with average volatility. The low price variable, which had much explanatory power in the cross-sectional regression, has zero explanatory power in a time-series context. The institutional ownership coefficient has the right sign, but a relatively low adjusted R-squared of around 8 percent. This result, taken together with the negative correlation we found in the cross-section regressions, suggests that institutional ownership cannot account for the trend. The multivariate regression produces an impressive adjusted R-squared of over 67 percent; however, we must be cautious in interpreting the results because of concerns about multicollinearity. Note that the coefficient of Nasdaq, no dividend, not regulated, and institutions (and interestingly its dummy variable) flip sign, suggesting that there may be some omitted variables bias in the univariate results. Interestingly the point estimate and statistical significance of turnover increases in the multivariate regression (the coefficient increases from 0.0283 to 0.1022 and the $t$-statistic increases from 2.7 to 8.8 ), suggesting that turnover is a particularly important determinant of the trend. Interestingly the multivariate regression has much lower serial correlation (i.e. DW close to 2) than the univariate regressions.

To further address the issue of serial correlation we include a lag of average volatility in the regression, whose results we report in Table $9 .^{24}$ Note the dramatic

\footnotetext{
${ }^{24}$ These time-series regression tests regress a highly persistent variable (i.e. average volatility) on highly persistent variables (e.g. average age or book-to-market). In a simulation experiment (available from the authors upon request), we demonstrate that inference in this context suffers from a spurious regressions problem related to the work of Ferson et al. (2003). We find that using Newey-West standard errors, as is
} 
reduction in serial correlation as the DW statistics are quite close to 2, particularly in the turnover and full-blown multivariate specifications. The R-square of the base AR(1) model (the first column) for the full sample is 38 percent, exceeding all of the previous univariate regressions. Interestingly, lagged volatility is much more important for the post-1994 years than the pre-1995 years. Note that for a variable to have a marginal contribution, the adjusted R-squared has to be more than $5.04 \%$ and $52.54 \%$ for the pre1995 and post-1994 periods respectively. It would be fair to say that we find a dramatic increase in the model fit after adding the predictors, especially for the post-1994 period. The best fitting individual explanatory variable is Maba with an adjusted R-squared of 47 percent for the full sample, followed by turnover with an adjusted R-squared of about 44 percent. We also observe that after the inclusion of lagged volatility, the coefficient of the variable VOLP, which was marginally significant in Table 8, is not significant in Table 9. However, age, no dividend, and Nasdaq remain significant (with the correct sign), and yield similar adjusted R-squared in the range of 41-42 percent. The results with regard to the full-blown regression are similar to those reported in Table 8. After including all variables the point estimate of turnover increases more than six-fold from 0.0158 to 0.0989 and the t-statistic more than doubles. We also observe that accounting for turnover, age, dividend policy, Nasdaq, and market-to-book (i.e., specifications (2)-(6)) causes a dramatic decrease in the coefficient on lagged volatility (decreasing from about 0.6 in the univariate to around 0.5 in the bivariate regressions), though the other variables (i.e., volatility of profitability, ROE, regulated dummy, institutions, and price) do not affect the autocorrelation coefficient. Finally in the full-blown multivariate model laggedthat arises in this context. However, simply including lagged average volatility as an explanatory variable is successful in correcting the standard errors and thus inference in this context. 
volatility is no longer statistically significant.

A quick perusal of Figure 1 leaves no doubt that October 1987 is an outlier. Because the number of observation in the time-series analysis is relatively small (128 observations), we want to make sure that this outlier does not drive our results. Therefore, as a robustness check, which we do not tabulate, we allow the intercept to differ in Q41987 and rerun the specification of Table 9. While the R-squared of all the specifications increase substantially (i.e., the Maba and turnover regression yield an R-squared of 64 percent and 69 percent respectively), there seems to be little difference in terms of the interpretation of the results.

Another way to control for possible outliers in the value-weighted measures would be to fit a regression by calculation Cook's D (Cook's D can be thought of as a general measure of observation influence) and excluding observation for which D is high. In Table 10 we follow Rousseeuw and Leroy (2003) in constructing robust regressions that calculate case weights from absolute residuals, and regresses again using those weights. Iterations stop when the maximum change in weights drops below a tolerance level. The convergence procedure we employ includes Huber weighting and biweighting. In Huber weighting, observations with small residuals get a weight of 1 , the larger the residual, the smaller the weight. With biweighting, all cases with a non-zero residual get down-weighted at least a little. The two different kinds of weight are used because Huber weights can have difficulties with severe outliers, and biweights can have difficulties converging or may yield multiple solutions. In short, the most influential points are dropped, and then cases with large absolute residuals are down-weighted.

The significance of the results is similar to those in Table 8. In particular the 
three most important variables of specification (12) of Table 8 are Turnover, Maba, and low price.

Finally, we test for the structural break in the data. Initially, we have asserted the break is at the end of 1994, but that observation was based on graphical methods and ad hoc sample splits are not very reliable. We therefore conduct in Table 11 a structural break analysis. The table provides the Elliott and Müller (2006) test statistic for time varying coefficients in a model where volatility is regressed on turnover, no dividend, Maba, and Nasdaq and age (these are the variables in Table 9 that come significant when used in the univariate regression with lag volatility). The test contrasts a stable regression model with an unstable alternative where the independent variables coefficients are a function of time. This very general specification nests many of the 'structural break' and 'time varying parameter' models in the literature, allowing for almost any pattern of variation in the coefficients of the independent variables. The null is that all regressions coefficients are fixed over time. We run the test for the period before the cut-off period and after the cut-period in order to find a cut-off date in which both sub periods reject the null. Interestingly, we find that our cut-off period was more or less on the point. The structural break test shows that either 1994q4 or 1995q1 are the only quarters where we cannot reject the null for both sub periods at the $10 \%$ level. $^{25}$

We next account for the break in the relationships between the variables in 1995. We allow for the intercept and the coefficients on all parameters to change after the end of 1994. The parameter estimates are reported in Table 12. For each model specification we report the estimate pre-break in the first column, and the change in the parameters post-break is reported in the second column. In the interest of saving space, we report the

\footnotetext{
${ }^{25}$ We thank an anonymous referee for suggesting the analysis of the structural break.
} 
results for the two most robust variables in the time series (i.e., turnover and Maba) and a full blown regression specification. ${ }^{26}$

Given the "hump" in the last decade, it should not be surprising that one can reject the null hypothesis of no-structural break. ${ }^{27}$ We observe that the coefficients on both variables are statistically significant in the post-1994 period, but are insignificant in the pre-1995 period. These results persist no matter whether one includes lagged volatility in the specification or not. While not reported, we find that the coefficients of other variables that track average volatility well (i.e., Nasdaq, no dividend, and age) are significant in the post-1994 period but not in the pre-1995 period. It seems that the "hump” in volatility is an unusual period, when many firm characteristics were associated with changes in volatility. This suggests the conclusion that the different explanations provided in the literature are essentially capturing the variation in volatility during the last decade rather than being explanations of the trend in volatility over the three decades.

Comparing the importance of Maba and turnover, Maba seems to track volatility marginally better as in the lagged volatility specification it produces an adjusted Rsquared of 52 percent, while the turnover specification provides for an adjusted Rsquared of 49 percent. However, we note in the last 2 columns of Table 12, which report the multivariate tests, that Maba is only marginally significant (t-statistic of 1.66), while turnover is highly significant (t-statistic of 5.72). We reiterate that because there is such high correlation between the explanatory variables we have a trade-off between a univariate and bivariate regressions that suffer from omitted variables and a multivariate

\footnotetext{
${ }^{26}$ In a different analysis, we run the regressions of table 8 and 9 for the pre-1995 and post-1994 period separately. The results are qualitatively similar; in particular, the R-squared for the pre-1995 are close to zero.

${ }^{27}$ To conserve space we omit the tests but these are available from the authors on request.
} 
regression analysis that suffers from the high correlation between the independent variables (and the high standard errors associated with it). We therefore should exercise caution when interpreting the results. However, taking into consideration all results, it seems that turnover has two important qualities for explaining the trend: it has a high correlation with volatility and yields a high Adj. R-squared in the univariate and bivariate regressions; and it "survives" the full blown regression specifications. Note that in the specification (6) of Table 11, lag volatility is completely driven out, and many of the other variables, who in the univariate specifications are correlated with the trend (age, no dividend, Nasdaq, VOLP), either flip sign or become insignificant.

\section{Conclusions}

We have studied the curious behavior of volatility during the turn of the Millennium. Contrary to the current literature, which has proposed many explanations to the trend in volatility, we concentrate our effort on empirically testing the relevance of the major proxies used in past studies. We conduct both a cross-sectional and time-series analyses as a viable explanation of the trend should also be related to firm-level level volatility.

We find that two recent explanations to the trend fail in either the time-series or cross-sectional context. The explanation of Brandt et al (2010) that idiosyncratic volatility changes are associated with retail investors' attraction to low stock prices fails in the time-series; while the explanation of Cao et al. (2008) that the increase in idiosyncratic volatility is associated with changes in managerial growth options fails in the cross-section. 
Our results suggest that these studies claims that they have identified important determinants of the observed patterns in volatility over time are somewhat overstated. We believe that Brandt et al. (2010) evidence should be interpreted as another explanation associated with firm level volatility, whose economic contribution to the overall trend in volatility is limited. It is quite puzzling that the strong time-series evidence in Cao et al. (2008) fails to materialize in the cross-section.

Overall our results suggest that it is difficult to claim that a specific explanation is the driver for the changes in volatility levels. Rather, we find that the variables most associated with the tech-bubble are important both in the time-series and cross-section analyses (e.g., Nasdaq classification indicator, dividend payment indicator, and age). Also, our time-series analysis suggests a structural break around 1995, which leads to an unusual "hump" in both volatility and many firm characteristics that are related to the technology run up and following melt down. These characteristics are not useful in explaining changes in volatility levels in the pre-1995 period.

\section{References}

Acharya, A., Pedersen, L., 2005. Asset pricing with liquidity risk. Journal of Financial Economics 77, 375-410.

Admati, A.R., Pfleiderer, P., 1988. A theory of intraday patterns: Volume and price variability. Review of Financial Studies 1, 3-40.

Amihud, Yakov, 2002. Illiquidity and stock Returns: Cross-section and time-series effects. Journal of Financial Markets 5, 31-56.

Bennett, J., Sias, R., 2006. Why company-specific risk changes over time? Financial 
Analysts Journal 62, 89-100.

Brandt, M.W., Brav, A., Graham, J.R., Kumar, A., 2010. The idiosyncratic volatility puzzle: Time trend or speculative episodes. Review of Financial Studies 23, 863-899.

Brown, G., Kapadia, N., 2007. Firm-specific risk and equity market development. Journal of Financial Economics 84, 358-388.

Campbell, J., Lettau, M., Malkiel, B., Xu, Y., 2001. Have individual stocks become more volatile? An empirical exploration of idiosyncratic risk. Journal of Finance 56, 1-43.

Cao, C., Simin, T.T., Zhao, J., 2008. Can growth options explain the trend in idiosyncratic risk? Review of Financial Studies 21, 2599-2633.

Carhart, M., 1997. On persistence in mutual fund performance. Journal of Finance 52, 57-82.

Chuang, Chia-Chang, Kuan, Chung-Ming, Lin, Hsin-Yi, 2009. Causality in quantiles and dynamic stock return-volume relations. Journal of Banking and Finance 33, 13511360.

Elliott, G., Müller, U.K., 2006. Efficient tests for general persistent time variation in regression coefficients. Review of Economic Studies 73, 907-940.

Epps, T., Epps, M., 1976. The stochastic dependence of security price changes and transaction volumes: Implications for the mixture-of-distributions hypothesis. Econometrica 44, 305-321.

Fame, E. F., French, K. R., 1993. Common risk factors in returns of stocks and bonds. Journal of Financial Economics 33, 3-56.

Fama, E. F., French, K.R., 2001. Disappearing dividends: Changing firm characteristics or lower propensity to pay? Journal of Financial Economics 60, 3-43. 
Fama, E., MacBeth, J., 1973. Risk, return, and equilibrium: Empirical tests. Journal of Political Economy 81, 607-636.

Ferson, Wayne E., Sarkissian, S., Simin, T.T., 2003. Spurious regressions in financial economics? Journal of Finance 58, 1393-1413.

Fink, J., Fink, K.E., Grullon, G., Weston, J., 2006. Firm age and fluctuations in idiosyncratic risk. Working paper, Rice University.

Fleming, J., Kirby, C., Ostdiek, B., 2006. Stochastic volatility, trading volume, and the daily flow of information. Journal of Business 79, 1551-1590.

Foster, F.D., Viswanathan, S., 1990. A theory of the interday variations in volume, variance, and trading costs in securities markets. Review of Financial Studies 3, 593624.

Harris, J., Raviv, A., 1993. Differences of opinion make a horse race. Review of Financial Studies 6, 473-506.

Hollifield, B., 2002. Comment on: Stock volatility in the new Millennium: How wacky is Nasdaq? Journal of Monetary Economics 49, 27-30.

Irvine, P., Pontiff, J., 2009. Idiosyncratic return volatility, cash flows, and product market competition. Review of Financial Studies 22, 1149-1177.

Karpoff, J., 1987. The relationship between price changes and trading volume: A survey. Journal of Financial and Quantitative Analysis 22, 109-126.

Kraus, A., Smith, M., 1996. Heterogeneous beliefs and the effect of replicatable options on asset prices. Review of Financial Studies 3, 723-756.

Lamoureux, C., Lastrapes, W., 1994. Endogenous trading volume and momentum in stock-return volatility. Journal of Business and Economic Statistics 12, 253-260. 
Newey, W.K., West, K.D., 1987. A simple, positive semi-definite, heteroskedasticity and autocorrelation consistent covariance matrix. Econometrica 55, 703-708.

Pastor, L., Veronesi, P., 2003. Stock valuation and learning about profitability. Journal of Finance 58, 1749-1789.

Petersen, M., 2009. Estimating standard errors in finance panel data sets: Comparing approaches. Review of Financial Studies 22, 435-480.

Richardson, M., Smith, T., 1994. A direct test of the mixture of distributions hypothesis: Measuring the daily flow of information. Journal of Financial and Quantitative Analysis 29, 101-116.

Rajgopal, S., Venkatachalam, M., 2010. Financial reporting quality and idiosyncratic volatility over the last four decades. Journal of Accounting and Economics, forthcoming.

Rousseeuw, P. J., Leroy, A. M., 2003. Robust Regression and Outlier Detection. Wiley: New York.

Rubin, A., Smith, D.R., 2009. Volatility, dividends and institutional ownership. Journal of Banking and Finance 33, 627-639.

Schwert, G. W., 1989. Why does stock market volatility change over time? Journal of Finance 44, 1115-1153.

Schwert, G. W., 2002. Stock volatility in the new Millennium: How wacky is Nasdaq? Journal of Monetary Economics 49, 3-26.

Tauchen, G.E., Pitts M., 1983. The price variability-volume relationship on speculative markets. Econometrica 51, 485-505.

Umutlu, M., Adeniz, L., Altay-Salih, A., 2010. The degree of financial liberalization and 
aggregated stock-return volatility in emerging markets. Journal of Banking and Finance 34, 509-521.

Wang, Z., 2010. Dynamics and causality in industry-specific volatility. Journal of Banking and Finance 34, 1688-1699.

Wei, S., Zhang C., 2006. Why did individual stocks become more volatile? Journal of Business 79, 259-291.

Xu, Y., Malkiel, B., 2003. Investigating the behavior of idiosyncratic volatility. Journal of Business 76, 613-643. 


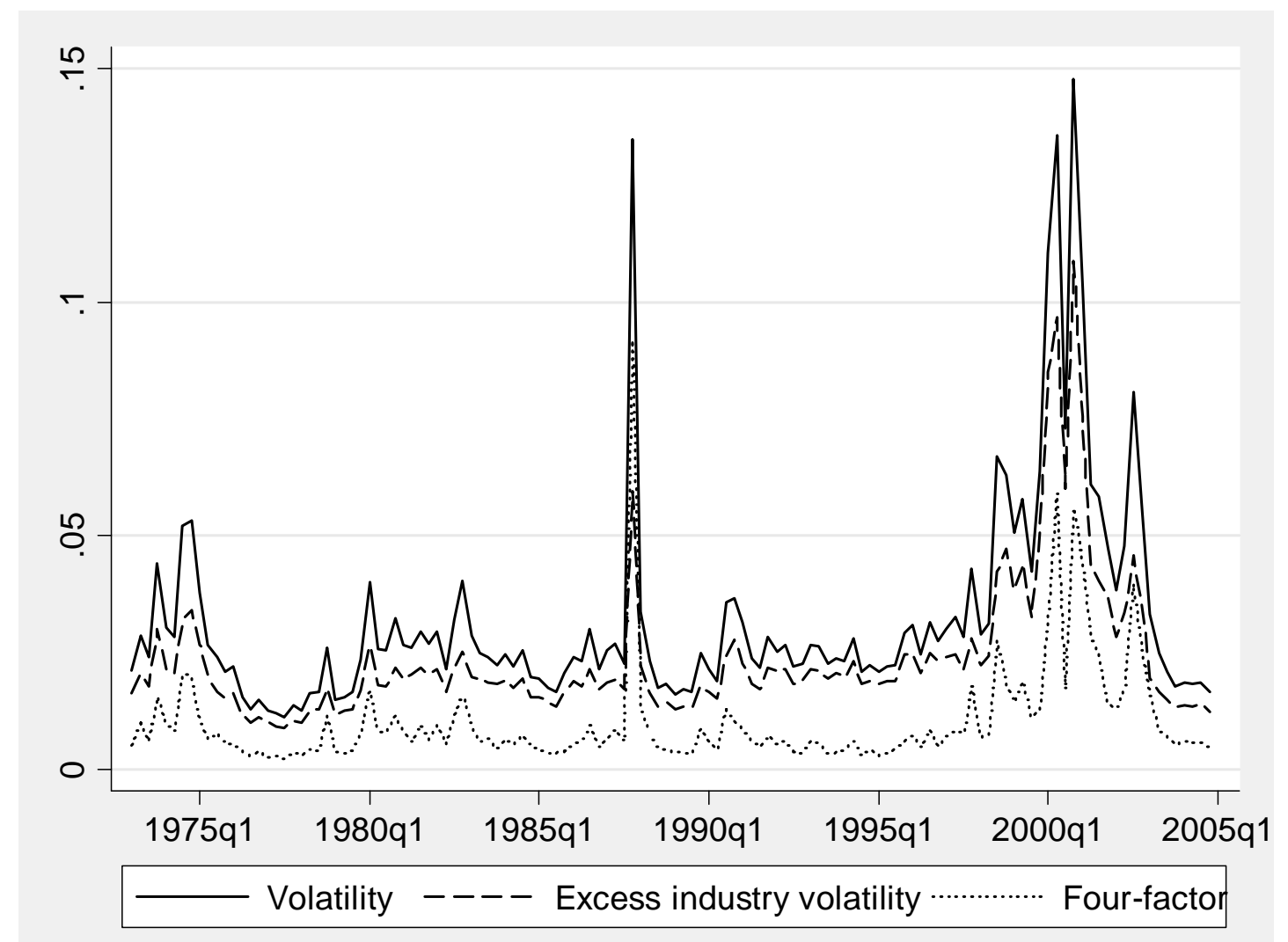

Figure 1: All measures are value-weighed and quarterly calculated over all NYSEAMEX-Nasdaq firms. Volatility is the sum of daily return squared. Excess industry volatility is the sum of excess return (daily return minus the corresponding Fama-French industry return). Four-factor is the sum of squared residual when a firm's daily return is regressed on the Fama-French-Carhart model. 

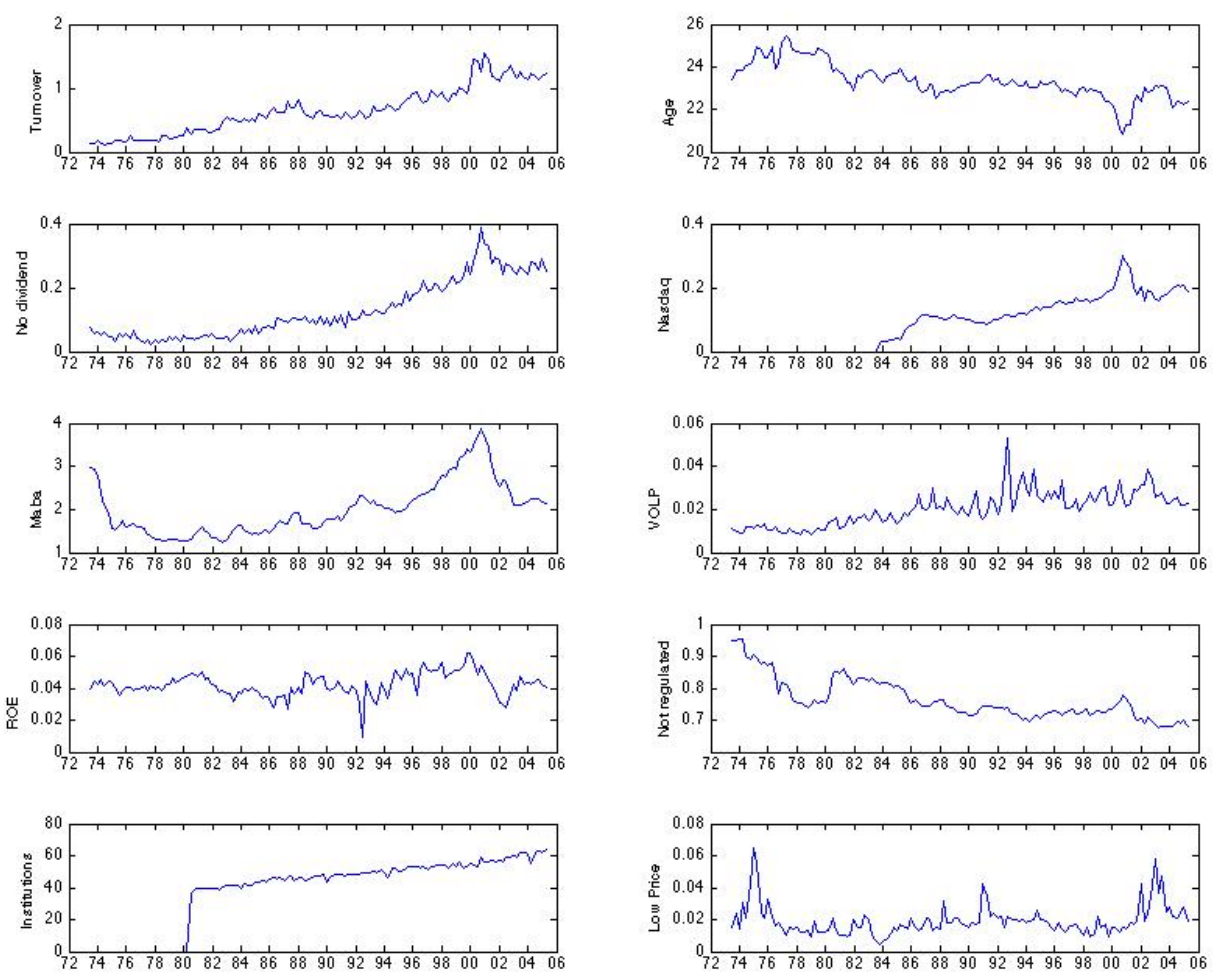

Figure 2: Time-series plot of value-weighted average of the explanatory variables 
Table 1

Prior Studies

We summarize the explanation provided in previous studies including the variable analyzed, the conditioning variables used in cross-sectional and timeseries regressions, and the way standard errors are computed for the time-series regressions. ROE is return on equity; VOLP is the time series volatility of ROE (typically based on 12 lags). Bold explanatory variable are proxies for the particular explanation provided in the paper. CLMX refers to the usage of the Campbell et al. (2001) methodology.

\begin{tabular}{|c|c|c|c|c|}
\hline 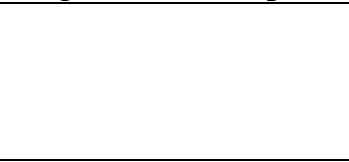 & Explanation provided & $\begin{array}{l}\text { Variable } \\
\text { analyzed is } \\
\text { computed based } \\
\text { on... }\end{array}$ & Sample period & $\begin{array}{l}\text { Cross-Sectional } \\
\text { Pooled - firm-level analysis }\end{array}$ \\
\hline Campbell et al. (2001) & & $\begin{array}{l}\text { Total volatility, } \\
\text { excess market, } \\
\text { excess industry } \\
\text { (CLMX) }\end{array}$ & $\begin{array}{l}\text { NYSE, AMEX, } \\
\text { Nasdaq firms 1962- } \\
1997\end{array}$ & \\
\hline Schwert (2002) & Nasdaq firms & Total volatility & & \\
\hline $\begin{array}{l}\text { Pastor and Veronesi } \\
\text { (2003) }\end{array}$ & $\begin{array}{l}\text { Firm profitability has } \\
\text { become more volatile }\end{array}$ & $\begin{array}{l}\text { Residual variance } \\
\text { of the market } \\
\text { model }\end{array}$ & $\begin{array}{l}\text { CRSP/Compustat } \\
1962-2000\end{array}$ & $\begin{array}{l}\text { Age, market to book, dividend } \\
\text { dummy, leverage, size, VOLP, } \\
\text { ROE. }\end{array}$ \\
\hline Xu and Malikiel (2003) & Earnings Growth & $\begin{array}{l}\text { Residual variance } \\
\text { of the market } \\
\text { model }\end{array}$ & $\begin{array}{l}\text { I/B/E/S sample } \\
\text { 1986-1995 }\end{array}$ & $\begin{array}{l}\text { Forecasted long term growth, } \\
\text { size }\end{array}$ \\
\hline Xu and Malkiel (2003) & $\begin{array}{l}\text { Increased importance of } \\
\text { institutions }\end{array}$ & Four-factor & $\begin{array}{l}\text { S\&P Firms 1989- } \\
1996\end{array}$ & Institutional ownership, size \\
\hline Brandt et al. (2010) & $\begin{array}{l}\text { Speculative episodes } \\
\text { concentrated in low } \\
\text { priced stock }\end{array}$ & $\begin{array}{l}\text { Excess industry } \\
(\mathrm{CLMX})\end{array}$ & $\begin{array}{l}\text { NYSE, AMEX, } \\
\text { Nasdaq firms (share } \\
\text { code 10,11) } \\
1962-2004\end{array}$ & $\begin{array}{l}\text { Price, size, market to book, } \\
\text { leverage, age, turnover, } \\
\text { institutional holdings }\end{array}$ \\
\hline Bennett and Sias (2006) & $\begin{array}{l}3 \text { factors - increased } \\
\text { value of riskier } \\
\text { industries, increased } \\
\text { role of small stock } \\
\text { firms, measurement } \\
\text { error associated within } \\
\text { industry concentration }\end{array}$ & $\begin{array}{l}\text { Excess industry } \\
(\mathrm{CLMX})\end{array}$ & & $\begin{array}{l}\text { Ratio of risky industries to } \\
\text { safe industries, ratio of } \\
\text { number of small companies to } \\
\text { large companies, the top } \\
\text { weighted average (across } \\
\text { industry) of each industry's } \\
\text { Herfindahl Index, time, lagged }\end{array}$ \\
\hline
\end{tabular}




\begin{tabular}{|c|c|c|c|c|c|c|}
\hline \multirow[b]{2}{*}{ Fink et al. (2006) } & \multirow[b]{2}{*}{$\begin{array}{l}\text { Decline in the age of } \\
\text { the typical public firm }\end{array}$} & \multirow[b]{2}{*}{$\begin{array}{l}\text { Excess industry } \\
(\mathrm{CLMX})\end{array}$} & \multirow[b]{2}{*}{$\begin{array}{l}\text { CRSP/Compustat } \\
\text { 1962-2004 }\end{array}$} & \multicolumn{2}{|l|}{ volatility } & \multirow[b]{2}{*}{ NA } \\
\hline & & & & $\begin{array}{l}\text { Age, time, size, market to book, } \\
\text { ROA, EPS, leverage, dividend } \\
\text { dummy, Exchanges dummy, } \\
\text { bubble dummy, crash dummy }\end{array}$ & Age & \\
\hline Cao et al. (2008) & $\begin{array}{l}\text { An increase in the level } \\
\text { and variance of growth } \\
\text { options available to } \\
\text { managers }\end{array}$ & $\begin{array}{l}\text { Excess industry } \\
(\mathrm{CLMX})\end{array}$ & & & $\begin{array}{l}\text { GO, VMABA, } \\
\text { ROE, VOLP }\end{array}$ & NW(12) \\
\hline
\end{tabular}


Table 2

\section{Correlations and Rank Spearman Correlations between Volatility Measures}

The table provides correlations (which are bold it they are significantly different than zero) and their corresponding rank (Spearman) correlations (in italics). The "sample" corresponds to all American firms traded on NYSE, AMEX and Nasdaq that have no missing values for all conditional variables (in a given quarter) used in this study. The population includes all firms traded on NYSE, AMEX and Nasdaq that have return data on the daily and monthly CRSP datasets. In panel A, the volatility measures are firm specific and the correlations are purely cross-sectional (the standard deviation of the correlation across quarters is provided in parenthesis below). Below the diagonal we provide the sample correlations (between the log variables), while above the diagonal we provide the population correlations. All measures are calculated each quarter during the period 1973q1-2005q1.Volatility is the sum of squared daily returns in a given quarter. Excess market is the sum of squared daily excess market return. Excess industry is the sum of squared daily excess industry return (based on the 49 Fama-French industries). Four-factors is the sum of daily squared errors when firm returns are regressed on the four-factors model (as in Brown and Kapadia, 2007). In Panel B below the diagonal we value weighted all measures the same way as done in Campbell et al. (2001). We provide time-series correlation and rank Spearman correlation based on all 128 quarters, while in parenthesis we calculate the correlation excluding quarter 1987q4. Above the diagonal we provide the same information for the equal-weighted measures.

Panel A: Cross Section Correlations

\begin{tabular}{|c|c|c|c|c|}
\hline & Volatility & Excess market & Excess industry & Four-factors \\
\hline Volatility & & $\begin{array}{c}\mathbf{0 . 9 7 0 0} 0.9832 \\
(0.027)\end{array}$ & $\begin{array}{c}\mathbf{0 . 9 3 3 8} 0.9608 \\
(0.053)\end{array}$ & $\begin{array}{c}\mathbf{0 . 7 9 6 9} 0.6691 \\
(0.030)\end{array}$ \\
\hline Excess market & $\begin{array}{c}\mathbf{0 . 9 7 9 5} 0.9814 \\
(0.027)\end{array}$ & & $\begin{array}{c}\mathbf{0 . 9 6 2 6} \\
0.9801 \\
(0.039)\end{array}$ & $\begin{array}{c}\mathbf{0 . 7 0 0} 0.5866 \\
(0.079)\end{array}$ \\
\hline Excess industry & $\begin{array}{c}\mathbf{0 . 7 2 8 2} 0.9620 \\
(0.169)\end{array}$ & $\begin{array}{c}\mathbf{0 . 7 4 5 8} 0.9849 \\
(0.1625)\end{array}$ & & $\begin{array}{c}\mathbf{0 . 6 6 9} 0.5557 \\
(0.087)\end{array}$ \\
\hline Four-factors & $\begin{array}{c}\mathbf{0 . 6 7 6 3} 0.7057 \\
(0.082)\end{array}$ & $\begin{array}{c}\mathbf{0 . 5 8 7 4}(0.6215 \\
(0.0959)\end{array}$ & $\begin{array}{c}\mathbf{0 . 4 2 1 5} 0.5931 \\
(0.1289)\end{array}$ & \\
\hline
\end{tabular}


Panel B: Time Series Correlations

\begin{tabular}{|c|c|c|c|c|c|c|c|c|}
\hline & $\begin{array}{l}\text { Volatility } \\
\text { - sample }\end{array}$ & $\begin{array}{c}\text { Excess } \\
\text { market - } \\
\text { sample }\end{array}$ & $\begin{array}{c}\text { Excess } \\
\text { industry - } \\
\text { sample }\end{array}$ & $\begin{array}{c}\text { Four- } \\
\text { factors - } \\
\text { sample }\end{array}$ & $\begin{array}{l}\text { Volatility } \\
\text { - pop. }\end{array}$ & $\begin{array}{c}\text { Excess } \\
\text { market - } \\
\text { pop. }\end{array}$ & $\begin{array}{c}\text { Excess } \\
\text { industry } \\
\text { - pop. }\end{array}$ & $\begin{array}{c}\text { Four- } \\
\text { factors - } \\
\text { pop. }\end{array}$ \\
\hline \multirow[t]{3}{*}{ Volatility - sample } & & 0.9958 & 0.9937 & 0.7098 & 0.8088 & 0.8116 & 0.8988 & 0.8127 \\
\hline & & 0.9967 & 0.9963 & 0.7414 & 0.6823 & 0.7277 & 0.8803 & 0.8644 \\
\hline & & $(0.9984)$ & $(0.9983)$ & $(0.7465)$ & $(0.7929)$ & $(0.8024)$ & $(0.9053)$ & $(0.8400)$ \\
\hline \multirow[t]{3}{*}{ Excess market - sample } & 0.9509 & & 0.9995 & 0.6564 & 0.7839 & 0.8049 & 0.9031 & 0.7672 \\
\hline & 0.9557 & & 0.9995 & 0.7207 & 0.6660 & 0.7147 & 0.8754 & 0.8455 \\
\hline & $(0.9802)$ & & $(0.9998)$ & $(0.7270)$ & $(0.7822)$ & $(0.7964)$ & $(0.9030)$ & $(0.8211)$ \\
\hline \multirow[t]{3}{*}{ Excess industry - sample } & 0.9519 & 0.9989 & & 0.6432 & 0.7835 & 0.8100 & 0.9033 & 0.7579 \\
\hline & 0.9563 & 0.9942 & & 0.7126 & 0.6576 & 0.7073 & 0.8770 & 0.8382 \\
\hline & $(0.9825)$ & $(0.9988)$ & & $(0.7276)$ & $(0.7882)$ & $(0.8031)$ & $(0.9022)$ & $(0.8229)$ \\
\hline \multirow[t]{3}{*}{ Four-factors - sample } & 0.9218 & 0.8002 & 0.7969 & & 0.8478 & 0.7186 & 0.4650 & 0.9571 \\
\hline & 0.8549 & 0.8354 & 0.8202 & & 0.8217 & 0.7673 & 0.4823 & 0.8945 \\
\hline & $(0.9335)$ & $(0.9030)$ & $(0.9011)$ & & $(0.8652)$ & $(0.8110)$ & $(0.5221)$ & $(0.9393)$ \\
\hline \multirow[t]{3}{*}{ Volatility - population } & 0.9865 & 0.9721 & 0.9708 & 0.9092 & & 0.9721 & 0.6215 & 0.8959 \\
\hline & 0.9595 & 0.9738 & 0.9699 & 0.9081 & & 0.9747 & 0.5721 & 0.8177 \\
\hline & $(0.9858)$ & $(0.9897)$ & $(0.9892)$ & $(0.9416)$ & & $(0.9900)$ & $(0.6258)$ & $(0.8958)$ \\
\hline \multirow[t]{3}{*}{ Excess market - pop. } & 0.9448 & 0.9957 & 0.9950 & 0.7899 & 0.9721 & & 0.6554 & 0.8029 \\
\hline & 0.9506 & 0.9878 & 0.9875 & 0.8084 & 0.9747 & & 0.6472 & 0.8158 \\
\hline & $(0.9737)$ & $(0.9955)$ & $(0.9948)$ & $(0.8900)$ & $(0.9900)$ & & $(0.6481)$ & $(0.8640)$ \\
\hline \multirow[t]{3}{*}{ Excess industry - pop. } & 0.9444 & 0.9942 & 0.9946 & 0.7860 & 0.9708 & 0.9996 & & 0.6555 \\
\hline & 0.9504 & 0.9799 & 0.9855 & 0.7928 & 0.9685 & 0.9970 & & 0.7507 \\
\hline & $(0.9736)$ & (0.9939) & $(0.9944)$ & $(0.8855)$ & $(0.9889)$ & $(0.9996)$ & & $(0.7252)$ \\
\hline \multirow[t]{3}{*}{ Four-factors - population } & 0.9430 & 0.8396 & 0.8375 & 0.9930 & 0.9377 & 0.8358 & 0.8329 & \\
\hline & 0.8659 & 0.8440 & 0.8316 & 0.9959 & 0.9177 & 0.8226 & 0.8089 & \\
\hline & $(0.9472)$ & $(0.9220)$ & $(0.9215)$ & $(0.9914)$ & $(0.9597)$ & $(0.9180)$ & $(0.9150)$ & \\
\hline
\end{tabular}


Table 4

Cross-Section Distribution - Before and After 1995

The sample includes all American firms traded on NYSE, AMEX and Nasdaq that have no missing observations in a given quarter. The sample has 5995 firms in the period 1973q1-1994q4, and 8986 firms in the period 1995q12005q1. Volatility is the volatility calculated as in Campbell et al (2001) based on daily returns. Turnover is the monthly average turnover (number of shares traded divided by number of shares outstanding). Age is the number of years since firm share appears on CRSP. Maba is market to book value of equity as calculated in Cao et al. (2008). VOLP is the variance of quarterly ROEs (Wei and Zhang, 2006). Institution is the combined holdings of all institutional investors. For indicator variables the mean value is provided. The indicator variables are: Nasdaq equals 1 if the firm is traded on Nasdaq; No dividend equals 1 if the firm did not pay dividend during the quarter (compustat item 16 is zero); Low price equals 1 if the firm's share price is lower than $\$ 10$ at the end of the quarter; Not regulated equals 1 if the firm is not classified to an industry whose first SIC code is 4 or 6 (financials and regulated).

\begin{tabular}{|c|c|c|c|c|c|c|c|c|c|}
\hline \multicolumn{10}{|c|}{ Pre-1995 } \\
\hline & Mean & $\begin{array}{l}\text { Standard } \\
\text { deviation }\end{array}$ & $\mathrm{p} 1$ & p5 & p25 & p50 & p75 & p95 & p99 \\
\hline Volatility & 0.06 & 0.24 & 0.00 & 0.01 & 0.02 & 0.03 & 0.07 & 0.20 & 0.51 \\
\hline Turnover & 0.54 & 0.67 & 0.03 & 0.07 & 0.18 & 0.34 & 0.64 & 1.66 & 3.39 \\
\hline Age & 15.74 & 9.00 & 2.16 & 3.50 & 7.92 & 14.35 & 22.68 & 30.00 & 30.00 \\
\hline Maba & 1.43 & 0.89 & 0.68 & 0.76 & 0.97 & 1.13 & 1.54 & 3.06 & 5.85 \\
\hline VOLP & 0.03 & 0.05 & 0.00 & 0.00 & 0.01 & 0.01 & 0.03 & 0.11 & 0.30 \\
\hline ROE & 0.02 & 0.07 & -0.37 & -0.06 & 0.02 & 0.03 & 0.05 & 0.08 & 0.16 \\
\hline Institution & 22.90 & 22.65 & 0.00 & 0.00 & 0.00 & 17.62 & 40.17 & 65.04 & 77.01 \\
\hline Dummy mean & Nasdaq & 0.24 & $\begin{array}{c}\text { No } \\
\text { dividend }\end{array}$ & 0.35 & Low price & 0.27 & $\begin{array}{c}\text { Not } \\
\text { regulated }\end{array}$ & 0.80 & \\
\hline \multicolumn{10}{|c|}{ Post-1994 } \\
\hline & Mean & $\begin{array}{l}\text { Standard } \\
\text { deviation }\end{array}$ & $\mathrm{p} 1$ & p5 & p25 & p50 & p75 & p95 & p99 \\
\hline Volatility & 0.11 & 0.25 & 0.00 & 0.01 & 0.02 & 0.05 & 0.11 & 0.37 & 0.88 \\
\hline Turnover & 1.18 & 1.42 & 0.05 & 0.12 & 0.36 & 0.71 & 1.41 & 3.91 & 7.64 \\
\hline Age & 14.08 & 9.43 & 2.08 & 3.25 & 5.92 & 11.09 & 22.68 & 30.00 & 30.00 \\
\hline Maba & 1.84 & 1.32 & 0.68 & 0.83 & 1.06 & 1.33 & 2.03 & 4.96 & 6.90 \\
\hline VOLP & 0.04 & 0.07 & 0.00 & 0.00 & 0.01 & 0.02 & 0.05 & 0.17 & 0.37 \\
\hline ROE & 0.00 & 0.11 & -0.50 & -0.20 & -0.00 & 0.02 & 0.04 & 0.09 & 0.21 \\
\hline Institution & 41.64 & 27.48 & 0.17 & 2.13 & 17.21 & 40.26 & 63.89 & 86.48 & 98.28 \\
\hline Dummy mean & Nasdaq & 0.53 & $\begin{array}{c}\text { No } \\
\text { dividend }\end{array}$ & 0.60 & Low price & 0.47 & $\begin{array}{c}\text { Not } \\
\text { regulated }\end{array}$ & 0.73 & \\
\hline
\end{tabular}


Table 5

\section{Cross-Section Correlation - Before and After 1995}

The sample includes all American firms traded on NYSE, AMEX and Nasdaq that have no missing observations in a given quarter. The sample has 5995 firms in the period 1973q1-1994q4, and 8986 firms in the period 1995q1-2005q1. Under the diagonal the table provides the average correlation in a given quarter (which is in bold if it is significantly greater than zero), the rank Spearman correlation (in italics), and the standard deviation of correlations (in parenthesis) for the period 1973q1-1994q4 (except of Inst, where the correlations are calculated for the period 1980q1-1994q4); above the diagonal, the same tabulation is provided for the period 1995q1-2005q1. Volatility is the log of the volatility calculated as in Campbell et al (2001) based on daily returns. Turnover is the monthly average turnover (number of shares traded divided by number of shares outstanding). Age is the number of years since firm share appears on CRSP. Maba is market to book value of equity as calculated in Cao et al. (2008). VOLP is the variance of quarterly ROEs (Wei and Zhang, 2006). Inst is the combined holdings of all institutional investors. The indicator variables are: Nasdaq equals 1 if the firm is traded on Nasdaq; No dividend equals 1 if the firm did not pay dividend during the quarter (compustat item 16 is zero); Low price equals 1 if the firm's share price is lower than $\$ 10$ at the end of the quarter; Not regulated equals 1 if the firm is not classified to an industry whose first SIC code is 4 or 6 (financials and regulated).

\begin{tabular}{|c|c|c|c|c|c|c|c|c|c|c|c|}
\hline & Volatility & Turnover & Age & $\begin{array}{l}\text { No } \\
\text { dividend }\end{array}$ & Nasdaq & Maba & VOLP & ROE & $\begin{array}{l}\text { Not } \\
\text { regulated }\end{array}$ & Inst & $\begin{array}{l}\text { Low } \\
\text { price }\end{array}$ \\
\hline \multirow[t]{3}{*}{ Volatility } & & 0.3562 & -0.3357 & 0.5856 & 0.4661 & 0.1596 & 0.3564 & -0.3682 & 0.3913 & -0.2765 & 0.5437 \\
\hline & & 0.3099 & -0.3226 & 0.5801 & 0.4516 & 0.0546 & 0.4166 & & 0.3802 & -0.2786 & 0.5385 \\
\hline & & (0.079) & $(0.072)$ & (0.029) & (0.073) & (0.079) & $(0.031)$ & $(0.040)$ & $(0.036)$ & $(0.076)$ & $(0.054)$ \\
\hline \multirow[t]{3}{*}{ Turnover } & 0.3008 & & -0.1734 & 0.2722 & 0.2231 & 0.3107 & 0.1185 & -0.069 & 0.2129 & 0.2531 & -0.0797 \\
\hline & 0.2873 & & -0.1292 & 0.2702 & 0.1517 & 0.3539 & 0.1883 & -0.0261 & 2629 & 4146 & -0.0973 \\
\hline & $(0.083)$ & & $(0.058)$ & $(0.056)$ & $(0.089)$ & $(0.065)$ & (0.058) & $(0.052)$ & $(0.027)$ & (0.119) & (0.073) \\
\hline \multirow[t]{3}{*}{ Age } & -0.3737 & -0.1193 & & 3906 & -0.3938 & -0.0994 & -0.1209 & 0.1667 & .0151 & & -0.2184 \\
\hline & 4017 & -0.8830 & & -0.3657 & -0.3584 & -0.0 & & 758 & 170 & & -0.2011 \\
\hline & $(0.081)$ & $(0.077)$ & & $(0.054)$ & $(0.035)$ & $(0.058)$ & $(0.020)$ & $(0.016)$ & $(0.033)$ & 25) & (0.029) \\
\hline No & & 0.18 & -0.3126 & & 0.3761 & 0.1 & 0.2 & & & & 4364 \\
\hline \multirow[t]{2}{*}{ dividend } & & & -0.36 & & 0.3738 & 0.1146 & 23 & & & & 4366 \\
\hline & .073) & $(0.075)$ & (0.115) & & $(0.037)$ & $(0.0$ & $(0.018)$ & & & & (0.035) \\
\hline \multirow[t]{3}{*}{ Nasdaq } & 0. & & & 0.2699 & & & & & & & 2627 \\
\hline & 3166 & 0.32 & -0.3 & 0.3443 & & 0.0676 & 0.1088 & & & & 612 \\
\hline & 215) & & $(0.1$ & (0.134) & & $(0.0$ & & & & & $(0.024)$ \\
\hline \multirow[t]{3}{*}{ Maba } & 0039 & 0.14 & -0.11 & 0.0190 & 0.1111 & & 0.1 & & & & -0.1038 \\
\hline & 0429 & 0.30 & -0.0942 & 0.0527 & 0.2251 & & 0.1140 & 0.2 & & & -0.2355 \\
\hline & 099) & & & $(0.072)$ & $(0.055)$ & & & & & & \\
\hline \multirow[t]{3}{*}{ VOLP } & 2935 & 0.07 & -0.0 & 0.2603 & 0.0224 & -0.0005 & & & & & 0.3070 \\
\hline & 3145 & 0.16 & -0.1086 & 0.3035 & 0.1151 & 0.0344 & & -0.2 & 92 & & 0.3643 \\
\hline & 051) & & & $(0.043)$ & $(0.0$ & $(0.0$ & & & & & 338) \\
\hline \multirow[t]{3}{*}{ ROE } & -0.1867 & 0.027 & 0.027 & -0.1429 & -0.0501 & 0.2055 & -0.1474 & & -0.1278 & & -0.3357 \\
\hline & -0.2023 & 0.0151 & 0.0458 & -0.2043 & -0.1014 & 0.3055 & -0.1586 & & -0.1294 & & -0.4032 \\
\hline & 124) & $(0.066)$ & $(($ & (0.908) & $(0.052)$ & $(0.08$ & $(0.232)$ & & & & $(0.041)$ \\
\hline Not & 0.2475 & 0.0908 & -0.0010 & 0.1515 & 0.0446 & 0.1138 & 0.0398 & -0.0507 & & 0.1003 & 0.2179 \\
\hline \multirow{2}{*}{ regulated } & 0.2542 & 0.0932 & -0.0143 & 0.1601 & 0.0272 & 0.1326 & 0.0764 & -0.0346 & & & 0.2202 \\
\hline & & $(0.061)$ & $(0.053)$ & $(0.083)$ & $(0.110)$ & $(0.048)$ & $(0.035)$ & & & & $(0.040)$ \\
\hline \multirow[t]{3}{*}{ Inst } & -0.3128 & 0.2141 & 0.2686 & -0.2415 & -0.1187 & 0.0686 & -0.1478 & 0.1299 & 0.0127 & & -0.4167 \\
\hline & & 0.3143 & 0.2735 & -0.2586 & -0.1176 & 0.1741 & 0.1806 & -0.1511 & -0.0144 & & -0.4325 \\
\hline & & & $(0.047)$ & $(0.033)$ & $(0.103)$ & $(0.041)$ & & & & & (0.044) \\
\hline \multirow[t]{3}{*}{ Low price } & 0.5352 & -0.0580 & -0.2722 & 0.4672 & 0.1783 & -0.1737 & 0.2627 & -0.2254 & 0.1158 & -0.4390 & \\
\hline & & -0.0569 & -0.3064 & 0.4800 & 0.1868 & -0.2498 & 0.2822 & -0.2881 & 0.1232 & -0.2367 & \\
\hline & $(0.098)$ & & $(0.075)$ & $(0.056)$ & $(0.106)$ & $(0.074)$ & $(0.053)$ & $(0.077)$ & $(0.043)$ & $(0.060)$ & \\
\hline
\end{tabular}




\section{Table 6 \\ The Cross-Section Determinants of Volatility - Before and After 1995}

The sample has 5995 firms in the period 1973q1-1994q4, and 8968 firms in the period 1995q1-2005q1. The table provides cross sectional regression for the different periods using (a) firm and quarter fixed-effects, and (b) double clustered stand errors as in Petersen (2009). Volatility is the log of the volatility calculated as in Campbell et al (2001) based on daily returns. Turnover is the monthly average turnover (number of shares traded divided by number of shares outstanding). Size is the log of the market value of the firm's common shares. Age is the number of years since firm share appears on CRSP. Maba is market to book value of equity as calculated in Cao et al. (2008). VOLP is the variance of quarterly ROEs (Wei and Zhang, 2006). Institution is the combined holdings of all institutional investors. The indicator variables are: Nasdaq equals 1 if the firm is traded on Nasdaq; No dividend equals 1 if the firm did not pay dividend during the quarter (compustat item 16 is zero); Low price equals 1 if the firm's share price is lower than $\$ 10$ at the end of the quarter; Not regulated equals 1 if the firm is not classified to an industry whose first SIC code is 4 or 6 (financials and regulated).All variables are normalized and $t$-statistic of coefficient is provided in parenthesis.

\begin{tabular}{lcccccc}
\hline \multirow{2}{*}{ Dependent } & \multicolumn{2}{c}{$1973 q 1-1994 q 4$} & \multicolumn{2}{c}{$1995 q 1-2005 q 1$} & \multicolumn{2}{c}{$1973 q 1-2005 q 1$} \\
& $1(\mathrm{a})$ & $1(\mathrm{~b})$ & $2(\mathrm{a})$ & $2(\mathrm{~b})$ & $3(\mathrm{a})$ & $3(\mathrm{~b})$ \\
\hline Lag volatility & 0.36284 & 0.60431 & 0.31426 & 0.62401 & 0.39897 & 0.61721 \\
& $(145.59)$ & $(23.09)$ & $(113.73)$ & $(36.01)$ & $(208.46)$ & $(40.80)$ \\
Size & -0.11217 & -0.06169 & -0.18721 & -0.05369 & -0.11889 & -0.05584 \\
& $(-18.76)$ & $(-4.82)$ & $(-29.34)$ & $(-5.06)$ & $(-28.97)$ & $(-4.73)$ \\
Turnover & 0.16368 & 0.19474 & 0.23362 & 0.12402 & 0.20172 & 0.13552 \\
& $(79.53)$ & $(10.51)$ & $(108.56)$ & $(17.53)$ & $(129.63)$ & $(17.38)$ \\
Age & -0.03087 & -0.03877 & -0.10792 & -0.01375 & -0.06465 & -0.02591 \\
& $(-4.91)$ & $(-8.17)$ & $(-7.01)$ & $(-3.07)$ & $(-16.25)$ & $(-6.89)$ \\
No dividend & 0.03041 & 0.04214 & 0.02565 & 0.04604 & 0.03257 & 0.04603 \\
& $(11.42)$ & $(7.88)$ & $(7.03)$ & $(8.63)$ & $(14.98)$ & $(11.53)$ \\
Nasdaq & 0.00920 & 0.01701 & 0.026186 & 0.03663 & 0.03088 & 0.02963 \\
& $(1.63)$ & $(1.65)$ & $(4.48)$ & $(5.61)$ & $(8.56)$ & $(4.85)$ \\
Maba & -0.00882 & 0.00908 & -0.00939 & 0.00739 & -0.00920 & 0.00736 \\
& $(-3.31)$ & $(1.24)$ & $(-3.56)$ & $(1.16)$ & $(-5.00)$ & $(1.30)$ \\
VOLP & 0.03256 & 0.02134 & 0.02195 & 0.02130 & 0.02393 & 0.02088 \\
& $(13.11)$ & $(4.72)$ & $(12.60)$ & $(5.05)$ & $(19.37)$ & $(6.49)$ \\
ROE & -0.04053 & -0.05105 & -0.04668 & -0.03894 & -0.04563 & -0.04057 \\
& $(-24.63)$ & $(-10.19)$ & $(-24.98)$ & $(-8.69)$ & $(-35.09)$ & $(-11.08)$ \\
Not regulated & -0.00529 & 0.05580 & 0.01356 & 0.06038 & 0.02384 & 0.05862 \\
Institutions & $(-0.56)$ & $(8.97)$ & $(1.72)$ & $(9.50)$ & $(4.44)$ & $(9.25)$ \\
& -0.00630 & -0.05385 & -0.02686 & -0.04560 & -0.02355 & -0.04775 \\
Low price & $(-1.94)$ & $(-2.58)$ & $(-6.68)$ & $(-4.16)$ & $(-9.13)$ & $(-3.53)$ \\
& 0.09975 & 0.11910 & 0.07800 & 0.09913 & 0.09879 & 0.10813 \\
& $(44.41)$ & $(17.64)$ & $(30.44)$ & $(12.31)$ & $(57.92)$ & $(19.65)$ \\
\hline \multirow{2}{*}{ Number of } & & & & & & \\
observations & 119,344 & 119,344 & 127,263 & 127,263 & 246,607 & 246,607 \\
R-squared & & & & & \\
& 0.7335 & 0.6902 & 0.7132 & 0.7237 & 0.7485 & 0.7186 \\
\hline
\end{tabular}


Table 7

Summary Statistics of Value-Weighted Averaged Time-Series Variables

Descriptive statistics of the value-weighted volatility and value-weighted averages of the ten conditioning variables. Panel A reports the mean and standard deviation for the full sample, the sub period 1973q1-1994q4, and the sub period 1995q1-2005q1respectively. Panel B provides correlation and Spearman correlation (above the diagonal) matrix of the full sample of value-weighted variables. Firm-level variables used to derive value-weighted variables are: volatility is calculated as in Campbell et al (2001) based on daily returns. Turnover is the monthly average turnover (number of shares traded divided by number of shares outstanding). Age is the number of years since firm share appears on CRSP. Maba is market to book value of equity as calculated in Cao et al. (2008). VOLP is the variance of quarterly ROEs (Wei and Zhang, 2006). Institution is the combined holdings of all institutional investors. The indicator variables are: Nasdaq equals 1 if the firm is traded on Nasdaq; No dividend equals 1 if the firm did not pay dividend during the quarter (compustat item 16 is zero); Low price equals 1 if the firm's share price is lower than $\$ 10$ at the end of the quarter; Not regulated equals 1 if the firm is not classified to an industry whose first SIC code is 4 or 6 (financials and regulated).

\begin{tabular}{|c|c|c|c|c|c|c|c|c|c|c|c|}
\hline \\
\hline & Volatility & Turnover & Age & $\begin{array}{c}\text { No } \\
\text { dividend }\end{array}$ & Nasdaq & Maba & VOLP & ROE & $\begin{array}{c}\text { Not } \\
\text { regulated }\end{array}$ & Institution & $\begin{array}{l}\text { Low } \\
\text { price }\end{array}$ \\
\hline Mean & 0.0288 & 0.6447 & 23.3392 & 0.1277 & 0.0923 & 2.0048 & 0.0203 & 0.0422 & 0.7643 & 38.7403 & 0.0193 \\
\hline $\mathrm{SD}$ & 0.0200 & 0.3603 & 0.8381 & 0.0895 & 0.0782 & 0.6168 & 0.0079 & 0.0074 & 0.0644 & 21.3886 & 0.0098 \\
\hline Mean (Pre-1995) & 0.0234 & 0.4417 & 23.6950 & 0.0730 & 0.0498 & 1.7005 & 0.0177 & 0.0400 & 0.7869 & 30.5901 & 0.0186 \\
\hline SD (Pre-1995) & 0.0139 & 0.2018 & 0.6847 & 0.0335 & 0.0518 & 0.3705 & 0.0078 & 0.0061 & 0.0649 & 21.4382 & 0.0093 \\
\hline Mean (Post-1994) & 0.0401 & 1.0754 & 22.5841 & 0.2439 & 0.1826 & 2.6504 & 0.0259 & 0.0468 & 0.7164 & 56.0346 & 0.0206 \\
\hline SD (Post-1994) & 0.0257 & 0.2117 & 0.6022 & 0.0519 & 0.0373 & 0.5332 & 0.0044 & 0.0079 & 0.0249 & 3.6477 & 0.0107 \\
\hline \multicolumn{12}{|c|}{ Panel B } \\
\hline Volatility & & 0.3683 & -0.3687 & 0.3729 & 0.3071 & 0.4779 & 0.3437 & 0.1621 & 0.0537 & 0.3129 & 0.1849 \\
\hline Turnover & 0.5094 & & -0.8881 & 0.9316 & 0.9563 & 0.6953 & 0.8500 & 0.2232 & -0.7639 & 0.7361 & 0.1491 \\
\hline Age & -0.4883 & -0.8361 & & -0.8807 & -0.8964 & -0.7102 & -0.7478 & -0.2662 & 0.6305 & -0.8444 & -0.1392 \\
\hline No dividend & 0.4964 & 0.934 & -0.8173 & & 0.9673 & 0.8385 & 0.8260 & 0.2507 & -0.7538 & 0.9435 & 0.2568 \\
\hline Nasdaq & 0.4388 & 0.9408 & -0.8705 & 0.9459 & & 0.7862 & 0.8272 & 0.2702 & -0.7879 & 0.9576 & 0.2088 \\
\hline Maba & 0.6046 & 0.6866 & -0.7122 & 0.8168 & 0.7656 & & 0.6448 & 0.4550 & -0.1300 & 0.7361 & 0.1990 \\
\hline VOLP & 0.2425 & 0.6908 & -0.6495 & 0.6500 & 0.7357 & 0.5100 & & 0.0920 & -0.7415 & 0.8425 & 0.2207 \\
\hline ROE & 0.2384 & 0.1885 & -0.2322 & 0.3121 & 0.2521 & 0.3679 & -0.0104 & & -0.1300 & 0.2347 & -0.1671 \\
\hline Not regulated & -0.0048 & -0.6886 & 0.4872 & -0.6042 & -0.7179 & -0.2434 & -0.6362 & -0.0595 & & -0.8172 & -0.2744 \\
\hline Low price & 0.1129 & 0.1062 & 0.0213 & 0.1423 & 0.0998 & 0.0077 & 0.0883 & -0.1111 & 0.0027 & 0.0015 & \\
\hline
\end{tabular}


Table 8

The Time-Series Determinants of Value-Weighted Average Volatility - Full Sample Results

The sample has 128 observations in the period 1973q1-2005q1. The dependent variable is value-weighted volatility. All variables are defined in Table

7. Each column contains a different specification of the regression model For each regression the adjusted R-squared from running the same specification regression for the pre-1995 and post-1994 periods separately. The table reports the point estimate and Newey-West $t$-statistics computed using 3 lags.

\begin{tabular}{|c|c|c|c|c|c|c|c|c|c|c|c|}
\hline & (1) & (2) & (3) & (4) & (5) & (6) & (7) & (8) & (9) & (10) & (11) \\
\hline Intercept & $\begin{array}{l}0.0105 \\
(1.84)\end{array}$ & $\begin{array}{l}0.3011 \\
(3.08)\end{array}$ & $\begin{array}{l}0.0146 \\
(3.69)\end{array}$ & $\begin{array}{l}0.0184 \\
(5.44)\end{array}$ & $\begin{array}{c}-0.0106 \\
(-1.25)\end{array}$ & $\begin{array}{l}0.0163 \\
(3.16)\end{array}$ & $\begin{array}{l}0.0016 \\
(0.11)\end{array}$ & $\begin{array}{l}0.0299 \\
(1.53)\end{array}$ & $\begin{array}{c}-0.0105 \\
(-0.72)\end{array}$ & $\begin{array}{l}0.0243 \\
(4.38)\end{array}$ & $\begin{array}{c}0.1394 \\
(1.35)\end{array}$ \\
\hline Turnover & $\begin{array}{c}0.0283 \\
(2.70)\end{array}$ & & & & & & & & & & $\begin{array}{c}0.1022 \\
(8.75)\end{array}$ \\
\hline Age & & $\begin{array}{r}-0.0117 \\
(-2.83)\end{array}$ & & & & & & & & & $\begin{array}{c}-0.0031 \\
(-0.80)\end{array}$ \\
\hline No dividend & & & $\begin{array}{l}0.1110 \\
(2.86)\end{array}$ & & & & & & & & $\begin{array}{l}-0.0989 \\
(-1.65)\end{array}$ \\
\hline Nasdaq & & & & $\begin{array}{c}0.1123 \\
(2.45)\end{array}$ & & & & & & & $\begin{array}{c}-0.0693 \\
(-0.93)\end{array}$ \\
\hline Maba & & & & & $\begin{array}{l}0.0196 \\
(4.32)\end{array}$ & & & & & & $\begin{array}{c}0.0201 \\
(4.54)\end{array}$ \\
\hline VOLP & & & & & & $\begin{array}{c}0.6136 \\
(1.98)\end{array}$ & & & & & $\begin{array}{l}0.2367 \\
(1.04)\end{array}$ \\
\hline ROE & & & & & & & $\begin{array}{l}0.6452 \\
(1.79)\end{array}$ & & & & $\begin{array}{l}0.3577 \\
(2.22)\end{array}$ \\
\hline Not regulated & & & & & & & & $\begin{array}{c}-0.0015 \\
(-0.06)\end{array}$ & & & $\begin{array}{c}0.0084 \\
(0.21)\end{array}$ \\
\hline Low price & & & & & & & & & & $\begin{array}{l}0.231 \\
(1.21)\end{array}$ & $\begin{array}{c}0.5385 \\
(4.17)\end{array}$ \\
\hline Pre-1980 Dummy & & & & & & & & & $\begin{array}{c}0.0325 \\
(2.15)\end{array}$ & & $\begin{array}{c}-0.1262 \\
(-5.16)\end{array}$ \\
\hline Adj. R-squared pre 95 & 0.0081 & 0.0134 & -0.0097 & -0.0117 & 0.0196 & -0.0115 & -0.0113 & 0.0385 & 0.0013 & 0.0484 & 0.2754 \\
\hline Adj. R-squared post 94 & 0.3865 & 0.3759 & 0.3183 & 0.3953 & 0.5874 & 0.0076 & -0.0051 & 0.3244 & -0.0003 & -0.0201 & 0.7652 \\
\hline Adj. R-squared & 0.2536 & 0.2324 & 0.2405 & 0.1861 & 0.3605 & 0.0513 & 0.0494 & -0.0079 & 0.0763 & 0.0049 & 0.6771 \\
\hline DW & 0.8757 & 1.0606 & 1.0332 & 0.9427 & 1.1713 & 0.8417 & 0.8379 & 0.7612 & 0.8491 & 0.7900 & 1.9812 \\
\hline
\end{tabular}


Table 9

The Time-Series Determinants of Value-Weighted Average Volatility - Full Sample Results

The sample has 128 observations in the period 1973q1-2005q1. The dependent variable is value-weighted volatility. All variables are defined in Table 7. Each column contains a different specification of the regression model. For each regression the adjusted R-squared is reported along with the DurbinWatson statistic (DW), and the R-squared from running the same specification regression for the pre-1995 and post-1994 periods separately. The table reports the point estimate and OLS $t$-statistics.

\begin{tabular}{|c|c|c|c|c|c|c|c|c|c|c|c|c|}
\hline & $(1)$ & $(2)$ & $(3)$ & $(4)$ & $(5)$ & $(6)$ & $(7)$ & $(8)$ & (9) & $(10)$ & $(11)$ & $(12)$ \\
\hline Intercept & $\begin{array}{l}0.0109 \\
(4.45)\end{array}$ & $\begin{array}{l}0.0045 \\
(1.57)\end{array}$ & $\begin{array}{l}0.1482 \\
(3.31)\end{array}$ & $\begin{array}{c}0.0076 \\
(2.91)\end{array}$ & $\begin{array}{l}0.0087 \\
(3.44)\end{array}$ & $\begin{array}{c}-0.0077 \\
(-1.74)\end{array}$ & $\begin{array}{c}0.0072 \\
(1.81)\end{array}$ & $\begin{array}{c}-0.0039 \\
(-0.48)\end{array}$ & $\begin{array}{c}0.0096 \\
(0.57)\end{array}$ & $\begin{array}{c}-0.0026 \\
(-0.22)\end{array}$ & $\begin{array}{l}0.0129 \\
(3.83)\end{array}$ & $\begin{array}{l}0.1200 \\
(1.15)\end{array}$ \\
\hline Lag volatility & $\begin{array}{l}0.6192 \\
(8.84)\end{array}$ & $\begin{array}{c}0.4878 \\
(6.49)\end{array}$ & $\begin{array}{l}0.4997 \\
(6.39)\end{array}$ & $\begin{array}{l}0.4944 \\
(6.25)\end{array}$ & $\begin{array}{l}0.5284 \\
(6.92)\end{array}$ & $\begin{array}{l}0.4103 \\
(5.31)\end{array}$ & $\begin{array}{l}0.5968 \\
(8.22)\end{array}$ & $\begin{array}{l}0.5958 \\
(8.46)\end{array}$ & $\begin{array}{c}0.6193 \\
(8.80)\end{array}$ & $\begin{array}{l}0.5831 \\
(7.86)\end{array}$ & $\begin{array}{c}0.6361 \\
(8.72)\end{array}$ & $\begin{array}{l}0.1053 \\
(1.37)\end{array}$ \\
\hline Turnover & & $\begin{array}{l}0.0158 \\
(3.79)\end{array}$ & & & & & & & & & & $\begin{array}{l}0.0989 \\
(8.31)\end{array}$ \\
\hline Age & & & $\begin{array}{c}-0.0057 \\
(-3.07)\end{array}$ & & & & & & & & & $\begin{array}{c}-0.0027 \\
(-0.71)\end{array}$ \\
\hline No dividend & & & & $\begin{array}{c}0.0543 \\
(3.07)\end{array}$ & & & & & & & & $\begin{array}{l}-0.1167 \\
(-1.91)\end{array}$ \\
\hline Nasdaq & & & & & $\begin{array}{l}0.0524 \\
(2.68)\end{array}$ & & & & & & & $\begin{array}{c}-0.0672 \\
(-0.90)\end{array}$ \\
\hline Maba & & & & & & $\begin{array}{c}0.0123 \\
(4.91)\end{array}$ & & & & & & $\begin{array}{l}0.0191 \\
(4.26)\end{array}$ \\
\hline VOLP & & & & & & & $\begin{array}{c}0.2134 \\
(1.16)\end{array}$ & & & & & $\begin{array}{c}0.2273 \\
(1.00)\end{array}$ \\
\hline ROE & & & & & & & & $\begin{array}{l}0.3677 \\
(1.93)\end{array}$ & & & & $\begin{array}{l}0.3569 \\
(2.22)\end{array}$ \\
\hline Institution & & & & & & & & & & $\begin{array}{c}0.0003 \\
(1.23)\end{array}$ & & $\begin{array}{l}-0.0031 \\
(-4.99)\end{array}$ \\
\hline Low price & & & & & & & & & & & $\begin{array}{c}-0.1258 \\
(-0.84)\end{array}$ & $\begin{array}{c}0.4542 \\
(3.18)\end{array}$ \\
\hline Pre-1980 Dummy & & & & & & & & & & $\begin{array}{c}0.0122 \\
(0.96) \\
\end{array}$ & & $\begin{array}{c}-0.1114 \\
(-4.18) \\
\end{array}$ \\
\hline Adj. R-squared pre 95 & 0.0504 & 0.0551 & 0.0533 & 0.0402 & 0.0391 & 0.0639 & 0.0391 & 0.0680 & 0.0399 & 0.0474 & 0.0617 & 0.2666 \\
\hline Adj. R-squared post 94 & 0.5254 & 0.6010 & 0.5561 & 0.5325 & 0.5598 & 0.6564 & 0.5130 & 0.5288 & 0.5931 & 0.5319 & 0.5328 & 0.8054 \\
\hline Adj. R-squared & 0.3777 & 0.4374 & 0.4168 & 0.4168 & 0.4069 & 0.4741 & 0.3794 & 0.3909 & 0.3728 & 0.3791 & 0.3763 & 0.6795 \\
\hline DW & 2.227 & 2.022 & 2.1643 & 2.1148 & 2.1457 & 2.0913 & 2.2025 & 2.2236 & 2.2276 & 2.2054 & 2.2373 & 2.1363 \\
\hline
\end{tabular}


Table 10

The Time-Series Determinants of Value-Weighted Average Volatility - Robust Regression Results

The table follows Rousseeuw and Leroy (2003) in constructing robust regressions that calculate case weights from absolute residuals, and regresses again using those weights. The weighting is done in two stages. In Huber weighting, observations with small residuals get a weight of 1 , the larger the residual, the smaller the weight. With biweighting, all cases with a non-zero residual get down-weighted at least a little. Using the Huber weights first helps to minimize problems with convergence when using biweights. Iterations stop when the maximum change in weights drops below a tolerance level. The dependent variable is value-weighted volatility. All variables are defined in Table 7. Each column contains a different specification of the regression model separately. All tables include an intercept. The table reports the point estimate t-statistics (in parenthesis).

\begin{tabular}{|c|c|c|c|c|c|c|c|c|c|c|c|}
\hline Turnover & $\begin{array}{c}(1) \\
0.0096 \\
(4.22)\end{array}$ & (2) & (3) & (4) & (5) & (6) & (7) & (8) & (9) & (10) & $\begin{array}{c}(11) \\
0.0417 \\
(7.10)\end{array}$ \\
\hline Age & & $\begin{array}{c}-0.0035 \\
(-4.09)\end{array}$ & & & & & & & & & $\begin{array}{c}-0.0033 \\
(-2.16)\end{array}$ \\
\hline No dividend & & & $\begin{array}{c}0.0505 \\
(5.41)\end{array}$ & & & & & & & & $\begin{array}{c}-0.0809 \\
(-2.92)\end{array}$ \\
\hline Nasdaq & & & & $\begin{array}{c}0.0272 \\
(2.57)\end{array}$ & & & & & & & $\begin{array}{c}-0.0693 \\
(-0.93)\end{array}$ \\
\hline Maba & & & & & $\begin{array}{l}0.0108 \\
(8.51)\end{array}$ & & & & & & $\begin{array}{c}0.0202 \\
(9.82)\end{array}$ \\
\hline VOLP & & & & & & $\begin{array}{c}0.2725 \\
(2.79)\end{array}$ & & & & & $\begin{array}{c}0.1590 \\
(1.58)\end{array}$ \\
\hline ROE & & & & & & & $\begin{array}{c}0.6452 \\
(1.69)\end{array}$ & & & & $\begin{array}{c}0.1996 \\
(2.68)\end{array}$ \\
\hline Not regulated & & & & & & & & $\begin{array}{c}0.1876 \\
(2.46)\end{array}$ & & & $\begin{array}{l}0.0121 \\
(0.70)\end{array}$ \\
\hline Institution & & & & & & & & & $\begin{array}{l}0.0002 \\
(2.76)\end{array}$ & & $\begin{array}{c}-0.00002 \\
(-0.23)\end{array}$ \\
\hline Low price & & & & & & & & & & $\begin{array}{l}0.496 \\
(6.11)\end{array}$ & $\begin{array}{c}0.541 \\
(10.07)\end{array}$ \\
\hline Pre-1980 Dummy & & & & & & & & & $\begin{array}{l}0.0059 \\
(1.64)\end{array}$ & & $\begin{array}{c}-0.0012 \\
(-0.45)\end{array}$ \\
\hline
\end{tabular}




\section{Table 11}

\section{Detection of Structural Break Analysis}

The table provides the Elliott and Müller (2006) test statistic for time varying coefficients where volatility is regressed on turnover, no dividend, Maba, and Nasdaq. The test contrasts a stable regression model with an unstable alternative where the independent variables coefficients depend are a function of time. This very general specification nests many of the 'structural break' and 'time varying parameter' models in the literature, allowing for almost any pattern of variation in the coefficients of the independent variables. The null is that all regressions coefficients are fixed over time. For rejecting the null, the $10 \%$ critical value is -23.37 , the $5 \%$ critical value is -25.29 , and the $1 \%$ critical value is -29.18 . In bold we provide values that do not reject the null of no structural break.

\begin{tabular}{lc|c}
\hline & $\begin{array}{c}\text { Test for the period preceding cut-off quarter } \\
\text { (excluding cut-off quarter) } \\
\text { Test statistic }\end{array}$ & $\begin{array}{c}\text { Test for the period following cut-off quarter } \\
\text { including cut-off quarter) } \\
\text { Test statistic }\end{array}$ \\
\hline 1990q1 & $\mathbf{- 2 2 . 6 6 5}$ & -32.297 \\
1991q1 & $\mathbf{- 2 2 . 4 4 7}$ & -31.621 \\
1992q1 & $\mathbf{- 2 2 . 3 0 6}$ & -31.592 \\
1993q1 & $\mathbf{- 2 1 . 3 6 6}$ & -31.602 \\
1994q1 & $\mathbf{- 2 1 . 7 1 4}$ & -29.376 \\
1994q2 & $\mathbf{- 2 4 . 2 8 6}$ & -29.705 \\
1994q3 & $\mathbf{- 2 2 . 2 4 8}$ & -25.555 \\
1994q4 & $\mathbf{- 2 2 . 4 7 1}$ & $\mathbf{- 2 1 . 8 7 3}$ \\
1995q1 & $\mathbf{- 2 2 . 3 5 4}$ & $\mathbf{- 1 9 . 4 0 1}$ \\
1995q2 & -25.407 & $\mathbf{- 1 9 . 1 5 1}$ \\
1995q3 & -27.205 & $\mathbf{- 1 8 . 8 3 9}$ \\
1995q4 & -30.195 & $\mathbf{- 1 9 . 0 0 5}$ \\
1996q1 & $-\mathbf{1 9 . 2 5 6}$ \\
1997q1 & -32.121 & $\mathbf{- 1 9 . 2 0 6}$ \\
1998q1 & -31.197 & $\mathbf{- 2 0 . 3 8 6}$ \\
1999q1 & -29.016 & $\mathbf{- 2 1 . 7 9 7}$ \\
2000q1 & -25.942 & $\mathbf{- 1 9 . 3 6 9}$ \\
\hline
\end{tabular}


Table 12

The Time-Series Determinants of Value-Weighted Average Volatility - Allowing for Break after 1994

The sample has 128 observations in the period 1973q1-2005q1. The dependent variable is value-weighted volatility. All variables are defined in Table 7. Models are collected in pairs of column: the first column reports the parameter estimate and $t$-statistic in the 1974-1994 period, and the second column is the difference between the pre-1995 and post-1994 periods. For each model we compute initially a model without accounting for lagged values of volatility (and compute the standard errors using Newey-West with 3 lags) and then with lagged volatility as a conditioning variable.

\begin{tabular}{|c|c|c|c|c|c|c|c|c|c|c|c|c|}
\hline \multirow[b]{2}{*}{ Intercept } & \multicolumn{2}{|c|}{$(1)$} & \multicolumn{2}{|c|}{$(2)$} & \multicolumn{2}{|c|}{ (3) } & \multicolumn{2}{|c|}{ (4) } & \multicolumn{2}{|c|}{ (5) } & \multicolumn{2}{|c|}{$(6)$} \\
\hline & $\begin{array}{l}0.0193 \\
(3.19)\end{array}$ & $\begin{array}{l}-0.062 \\
(-2.44)\end{array}$ & $\begin{array}{l}0.0139 \\
(3.12)\end{array}$ & $\begin{array}{l}-0.0409 \\
(-3.17)\end{array}$ & $\begin{array}{l}0.0122 \\
(2.11)\end{array}$ & $\begin{array}{l}-0.0716 \\
(-4.08)\end{array}$ & $\begin{array}{l}0.0079 \\
(1.08)\end{array}$ & $\begin{array}{l}-0.0488 \\
(-3.35)\end{array}$ & $\begin{array}{l}0.1240 \\
(1.86)\end{array}$ & $\begin{array}{l}-0.4976 \\
(-2.82)\end{array}$ & $\begin{array}{l}0.1301 \\
(1.08)\end{array}$ & $\begin{array}{l}-0.5176 \\
(-1.55)\end{array}$ \\
\hline Lag volatility & & & $\begin{array}{l}0.242 \\
(2.17)\end{array}$ & $\begin{array}{l}0.3199 \\
(2.10)\end{array}$ & & & $\begin{array}{l}0.2348 \\
(2.17)\end{array}$ & $\begin{array}{l}0.1473 \\
(0.91)\end{array}$ & & & $\begin{array}{c}-0.0386 \\
(-0.36)\end{array}$ & $\begin{array}{l}0.1112 \\
(0.65)\end{array}$ \\
\hline Turnover & $\begin{array}{l}0.0094 \\
(0.68)\end{array}$ & $\begin{array}{l}0.0677 \\
(2.32)\end{array}$ & $\begin{array}{l}0.0086 \\
(1.12)\end{array}$ & $\begin{array}{l}0.0327 \\
(2.22)\end{array}$ & & & & & $\begin{array}{l}0.1169 \\
(2.28)\end{array}$ & $\begin{array}{c}-0.0136 \\
(-0.25)\end{array}$ & $\begin{array}{l}0.1181 \\
(5.72)\end{array}$ & $\begin{array}{c}-0.0145 \\
(-0.53)\end{array}$ \\
\hline Age & & & & & & & & & $\begin{array}{l}-0.0058 \\
(-2.05)\end{array}$ & $\begin{array}{l}0.0087 \\
(1.08)\end{array}$ & $\begin{array}{c}-0.0061 \\
(-1.28)\end{array}$ & $\begin{array}{l}0.0102 \\
(0.68)\end{array}$ \\
\hline No dividend & & & & & & & & & $\begin{array}{l}0.0395 \\
(0.60)\end{array}$ & $\begin{array}{c}-0.0359 \\
(-0.34)\end{array}$ & $\begin{array}{l}0.0422 \\
(0.34)\end{array}$ & $\begin{array}{c}-0.0461 \\
(-0.26)\end{array}$ \\
\hline Nasdaq & & & & & & & & & $\begin{array}{l}-0.3041 \\
(-3.92)\end{array}$ & $\begin{array}{l}0.0804 \\
(0.42)\end{array}$ & $\begin{array}{c}-0.3095 \\
(-2.73)\end{array}$ & $\begin{array}{l}0.1060 \\
(0.29)\end{array}$ \\
\hline Maba & & & & & $\begin{array}{l}0.0066 \\
(1.94)\end{array}$ & $\begin{array}{l}0.0310 \\
(4.34)\end{array}$ & $\begin{array}{l}0.0079 \\
(1.44)\end{array}$ & $\begin{array}{l}0.0189 \\
(2.68)\end{array}$ & $\begin{array}{l}0.0124 \\
(1.88)\end{array}$ & $\begin{array}{l}0.0098 \\
(1.13)\end{array}$ & $\begin{array}{l}0.0122 \\
(1.66)\end{array}$ & $\begin{array}{l}0.0077 \\
(0.65)\end{array}$ \\
\hline VOLP & & & & & & & & & $\begin{array}{l}0.1413 \\
(1.10)\end{array}$ & $\begin{array}{c}-0.1603 \\
(-0.48)\end{array}$ & $\begin{array}{l}0.1483 \\
(0.53)\end{array}$ & $\begin{array}{l}-0.1711 \\
(-0.30)\end{array}$ \\
\hline ROE & & & & & & & & & $\begin{array}{l}0.4140 \\
(1.42)\end{array}$ & $\begin{array}{c}-0.3686 \\
(-0.85)\end{array}$ & $\begin{array}{l}0.4116 \\
(1.89)\end{array}$ & $\begin{array}{c}-0.3173 \\
(-0.73)\end{array}$ \\
\hline Not regulated & & & & & & & & & $\begin{array}{l}0.0063 \\
(0.22)\end{array}$ & $\begin{array}{l}0.4226 \\
(3.08)\end{array}$ & $\begin{array}{l}0.0081 \\
(0.15)\end{array}$ & $\begin{array}{l}0.3978 \\
(1.79)\end{array}$ \\
\hline Institution & & & & & & & & & $\begin{array}{c}-0.0015 \\
(-1.31)\end{array}$ & $\begin{array}{c}-0.0003 \\
(-0.23)\end{array}$ & $\begin{array}{c}-0.0015 \\
(-1.19)\end{array}$ & $\begin{array}{c}-0.0003 \\
(-0.16)\end{array}$ \\
\hline Low price & & & & & & & & & $\begin{array}{l}0.5926 \\
(5.15)\end{array}$ & $\begin{array}{c}-0.0727 \\
(-0.37)\end{array}$ & $\begin{array}{l}0.6225 \\
(3.22)\end{array}$ & $\begin{array}{l}-0.1960 \\
(-0.53)\end{array}$ \\
\hline Pre-1980 Dummy & & & & & & & & & $\begin{array}{c}-0.0405 \\
(-1.02) \\
\end{array}$ & & $\begin{array}{c}-0.0412 \\
(-0.79)\end{array}$ & \\
\hline $\begin{array}{l}\text { Adj. R-squared } \\
\text { DW }\end{array}$ & $\begin{array}{l}0 . \\
0 .\end{array}$ & & $\begin{array}{l}0 . \\
1 .\end{array}$ & & $\begin{array}{l}0 . \\
1 .\end{array}$ & & $\begin{array}{l}0 . \\
2 .\end{array}$ & & $\begin{array}{l}0 . \\
2 .\end{array}$ & & $\begin{array}{l}0 . \\
2 .\end{array}$ & \\
\hline
\end{tabular}




\section{List of NCER Working Papers}

No. 67 (Download full text)

Wagner Piazza Gaglianone, Luiz Renato Lima, Oliver Linton and Daniel Smith

Evaluating Value-at-Risk Models via Quantile Regression

No. 66 (Download full text)

Ralf Becker, Adam Clements and Robert O'Neill

A Kernel Technique for Forecasting the Variance-Covariance Matrix

No. 65 (Download full text)

Stan Hurn, Andrew McClelland and Kenneth Lindsay

A quasi-maximum likelihood method for estimating the parameters of multivariate diffusions

No. 64 (Download full text)

Ralf Becker and Adam Clements

Volatility and the role of order book structure?

No. 63 (Download full text)

Adrian Pagan

Can Turkish Recessions be Predicted?

No. 62 (Download full text)

Lionel Page and Katie Page

Evidence of referees' national favouritism in rugby

No. 61 (Download full text)

Nicholas King, P Dorian Owen and Rick Audas

Playoff Uncertainty, Match Uncertainty and Attendance at Australian National Rugby League Matches

No. 60 (Download full text)

Ralf Becker, Adam Clements and Robert O'Neill

A Cholesky-MIDAS model for predicting stock portfolio volatility

No. 59 (Download full text)

P Dorian Owen

Measuring Parity in Sports Leagues with Draws: Further Comments

No. 58 (Download full text)

Don Harding

Applying shape and phase restrictions in generalized dynamic categorical models of the business cycle

No. 57 (Download full text)

Renee Fry and Adrian Pagan

Sign Restrictions in Structural Vector Autoregressions: A Critical Review 
No. 56 (Download full text)

Mardi Dungey and Lyudmyla Hvozdyk

Cojumping: Evidence from the US Treasury Bond and Futures Markets

No. 55 (Download full text)

Martin G. Kocher, Marc V. Lenz and Matthias Sutter

Psychological pressure in competitive environments: Evidence from a randomized natural experiment: Comment

No. 54 (Download full text)

Adam Clements and Annastiina Silvennoinen

Estimation of a volatility model and portfolio allocation

No. 53 (Download full text)

Luis Catão and Adrian Pagan

The Credit Channel and Monetary Transmission in Brazil and Chile: A Structured VAR

Approach

No. 52 (Download full text)

Vlad Pavlov and Stan Hurn

Testing the Profitability of Technical Analysis as a Portfolio Selection Strategy

No. 51 (Download full text)

Sue Bridgewater, Lawrence M. Kahn and Amanda H. Goodall

Substitution Between Managers and Subordinates: Evidence from British Football

No. 50 (Download full text)

Martin Fukac and Adrian Pagan

Structural Macro-Econometric Modelling in a Policy Environment

No. 49 (Download full text)

Tim M Christensen, Stan Hurn and Adrian Pagan

Detecting Common Dynamics in Transitory Components

No. 48 (Download full text)

Egon Franck, Erwin Verbeek and Stephan Nüesch

Inter-market Arbitrage in Sports Betting

No. 47 (Download full text)

Raul Caruso

Relational Good at Work! Crime and Sport Participation in Italy. Evidence from Panel Data Regional Analysis over the Period 1997-2003.

No. 46 (Download full text) (Accepted)

Peter Dawson and Stephen Dobson

The Influence of Social Pressure and Nationality on Individual Decisions: Evidence from the Behaviour of Referees

No. 45 (Download full text)

Ralf Becker, Adam Clements and Christopher Coleman-Fenn

Forecast performance of implied volatility and the impact of the volatility risk premium 
No. 44 (Download full text)

Adam Clements and Annastiina Silvennoinen

On the economic benefit of utility based estimation of a volatility model

No. 43 (Download full text)

Adam Clements and Ralf Becker

A nonparametric approach to forecasting realized volatility

No. 42 (Download full text)

Uwe Dulleck, Rudolf Kerschbamer and Matthias Sutter

The Economics of Credence Goods: On the Role of Liability, Verifiability, Reputation and Competition

No. 41 (Download full text)

Adam Clements, Mark Doolan, Stan Hurn and Ralf Becker

On the efficacy of techniques for evaluating multivariate volatility forecasts

No. 40 (Download full text)

Lawrence M. Kahn

The Economics of Discrimination: Evidence from Basketball

No. 39 (Download full text)

Don Harding and Adrian Pagan

An Econometric Analysis of Some Models for Constructed Binary Time Series

No. 38 (Download full text)

Richard Dennis

Timeless Perspective Policymaking: When is Discretion Superior?

No. 37 (Download full text)

Paul Frijters, Amy Y.C. Liu and Xin Meng

Are optimistic expectations keeping the Chinese happy?

No. 36 (Download full text)

Benno Torgler, Markus Schaffner, Bruno S. Frey, Sascha L. Schmidt and Uwe Dulleck

Inequality Aversion and Performance in and on the Field

No. 35 (Download full text)

T M Christensen, A. S. Hurn and K A Lindsay

Discrete time-series models when counts are unobservable

No. 34 (Download full text)

Adam Clements, A S Hurn and K A Lindsay

Developing analytical distributions for temperature indices for the purposes of pricing temperature-based weather derivatives

No. 33 (Download full text)

Adam Clements, A S Hurn and K A Lindsay

Estimating the Payoffs of Temperature-based Weather Derivatives 
No. 32 (Download full text)

T M Christensen, A S Hurn and K A Lindsay

The Devil is in the Detail: Hints for Practical Optimisation

No. 31 (Download full text)

Uwe Dulleck, Franz Hackl, Bernhard Weiss and Rudolf Winter-Ebmer

Buying Online: Sequential Decision Making by Shopbot Visitors

No. 30 (Download full text)

Richard Dennis

Model Uncertainty and Monetary Policy

No. 29 (Download full text)

Richard Dennis

The Frequency of Price Adjustment and New Keynesian Business Cycle Dynamics

No. 28 (Download full text)

Paul Frijters and Aydogan Ulker

Robustness in Health Research: Do differences in health measures, techniques, and time frame matter?

No. 27 (Download full text)

Paul Frijters, David W. Johnston, Manisha Shah and Michael A. Shields

Early Child Development and Maternal Labor Force Participation: Using Handedness as an Instrument

No. 26 (Download full text)

Paul Frijters and Tony Beatton

The mystery of the U-shaped relationship between happiness and age.

No. 25 (Download full text)

T M Christensen, A S Hurn and K A Lindsay

It never rains but it pours: Modelling the persistence of spikes in electricity prices

No. 24 (Download full text)

Ralf Becker, Adam Clements and Andrew McClelland

The Jump component of S\&P 500 volatility and the VIX index

No. 23 (Download full text)

A. S. Hurn and V.Pavlov

Momentum in Australian Stock Returns: An Update

No. 22 (Download full text)

Mardi Dungey, George Milunovich and Susan Thorp

Unobservable Shocks as Carriers of Contagion: A Dynamic Analysis Using Identified

Structural GARCH

No. 21 (Download full text) (forthcoming)

Mardi Dungey and Adrian Pagan

Extending an SVAR Model of the Australian Economy 
No. 20 (Download full text)

Benno Torgler, Nemanja Antic and Uwe Dulleck

Mirror, Mirror on the Wall, who is the Happiest of Them All?

No. 19 (Download full text)

Justina AV Fischer and Benno Torgler

Social Capital And Relative Income Concerns: Evidence From 26 Countries

No. 18 (Download full text)

Ralf Becker and Adam Clements

Forecasting stock market volatility conditional on macroeconomic conditions.

No. 17 (Download full text)

Ralf Becker and Adam Clements

Are combination forecasts of S\&P $\mathbf{5 0 0}$ volatility statistically superior?

No. 16 (Download full text)

Uwe Dulleck and Neil Foster

Imported Equipment, Human Capital and Economic Growth in Developing Countries

No. 15 (Download full text)

Ralf Becker, Adam Clements and James Curchin

Does implied volatility reflect a wider information set than econometric forecasts?

No. 14 (Download full text)

Renee Fry and Adrian Pagan

Some Issues in Using Sign Restrictions for Identifying Structural VARs

No. 13 (Download full text)

Adrian Pagan

Weak Instruments: A Guide to the Literature

No. 12 (Download full text)

Ronald G. Cummings, Jorge Martinez-Vazquez, Michael McKee and Benno Torgler

Effects of Tax Morale on Tax Compliance: Experimental and Survey Evidence

No. 11 (Download full text)

Benno Torgler, Sascha L. Schmidt and Bruno S. Frey

The Power of Positional Concerns: A Panel Analysis

No. 10 (Download full text)

Ralf Becker, Stan Hurn and Vlad Pavlov

Modelling Spikes in Electricity Prices

No. 9 (Download full text)

A. Hurn, J. Jeisman and K. Lindsay

Teaching an Old Dog New Tricks: Improved Estimation of the Parameters of Stochastic Differential Equations by Numerical Solution of the Fokker-Planck Equation 
No. 8 (Download full text)

Stan Hurn and Ralf Becker

Testing for nonlinearity in mean in the presence of heteroskedasticity.

No. 7 (Download full text) (published)

Adrian Pagan and Hashem Pesaran

On Econometric Analysis of Structural Systems with Permanent and Transitory Shocks and Exogenous Variables.

No. 6 (Download full text) (published)

Martin Fukac and Adrian Pagan

Limited Information Estimation and Evaluation of DSGE Models.

No. 5 (Download full text)

Andrew E. Clark, Paul Frijters and Michael A. Shields

Income and Happiness: Evidence, Explanations and Economic Implications.

No. 4 (Download full text)

Louis J. Maccini and Adrian Pagan

Inventories, Fluctuations and Business Cycles.

No. 3 (Download full text)

Adam Clements, Stan Hurn and Scott White

Estimating Stochastic Volatility Models Using a Discrete Non-linear Filter.

No. 2 (Download full text)

Stan Hurn, J.Jeisman and K.A. Lindsay

Seeing the Wood for the Trees: A Critical Evaluation of Methods to Estimate the Parameters of Stochastic Differential Equations.

No. 1 (Download full text)

Adrian Pagan and Don Harding

The Econometric Analysis of Constructed Binary Time Series. 